\title{
Eastern Mediterranean biogeochemical flux model - Simulations of the pelagic ecosystem
}

\author{
G. Petihakis ${ }^{1}$, G. Triantafyllou ${ }^{1}$, K. Tsiaras ${ }^{1}$, G. Korres ${ }^{1}$, A. Pollani ${ }^{1}$, and I. Hoteit ${ }^{2}$ \\ ${ }^{1}$ Institute of Oceanography, Hellenic Center for Marine Research, P.O. BOX 2214, Iraklion-Crete Greece, GR 71003, Greece \\ ${ }^{2}$ Scripps Institution of Oceanography, La Jolla, CA, USA
}

\begin{abstract}
During the second phase (2003-2006) of the Mediterranean ocean Forecasting System Project (MFS) named Toward Environmental Predictions (MFSTEP) one of the three major aims was the development of numerical forecasting systems. In this context a generic Biogeochemical Flux Model (BFM) was developed and coupled with hydrodynamic models already operating at basin scale as well as in regional areas. In the Eastern Mediterranean basin the BFM was coupled with the Aegean Levantine Eddy Resolving MOdel (ALERMO). The BFM is a generic highly complex model based on ERSEM and although a detailed description of the model and its components is beyond the scope of this work, a short overview of the main processes, laying emphasis on the parameter values used is presented. In addition the performance of the model is evaluated with some preliminary results being qualitatively compared against field observations. The model in its present form is rather promising and reproduces all important major features although there are some slight inefficiencies mostly related to primary and bacterial productivity rates.
\end{abstract}

\section{Introduction}

The Mediterranean basin displays a great variety of climatic, physical, ecological, social, economic and cultural traits. Nevertheless and in spite of the apparent diversity the Mediterranean region has long been recognised as a single functional climatic, ecological, economic and social system. This semi-enclosed sea, which represents only $0.69 \%$ of the global ocean surface and $0.27 \%$ of the global ocean volume, contains several deep basins as well as a number of large and relatively shallow bays. Some of the largest rivers of Eu-

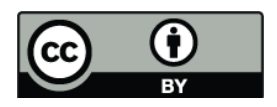

Correspondence to: G. Petihakis (pet@her.hcmr.gr) rope and Africa drain their nutrients and sediment-rich waters into the Mediterranean. About $92 \%$ of the estimated natural riverine input of $15000 \mathrm{~m}^{3} / \mathrm{s}$ is from the northern shores. However the management of these inputs has significantly reduced their discharge influencing large areas of the basin. In order to balance the approximately $3250 \mathrm{~km}^{3} / \mathrm{yr}$ water loss (Evaporation - Precipitation - Rivers - Black Sea) there is an influx of Atlantic waters through the straits of Gibraltar (Bryden et al., 1994).

Earlier studies on the Mediterranean system (McGill, 1965; Mihailov, 1964) provided evidence that the basin is characterised as oligotrophic, while later studies (Moutin and Raimbault, 2002) showed a well-defined eastward decreasing trend in primary productivity. The main mechanism responsible is the anti-estuarine circulation with surface Atlantic Water (AW), low in salinity and nutrients, after following the north coast of Africa reaches the central Levantine basin. There during winter cooling, it increases in density and sinks at $\sim 300 \mathrm{~m}$ forming the Levantine Intermediate Water (LIW), a water mass saltier and richer in dissolved nutrients (Theocharis et al., 1993). LIW following a parallel course with AW but moving in the opposite direction, eventually outflows into the Atlantic (Pinardi and Masetti, 2000) contributing to the impoverishment of the basin.

There are two distinct basins in the Mediterranean separated by the shallow Sicily Strait $(\sim 500 \mathrm{~m})$ which limits exchange, thus decoupling hydrodynamic and ecological conditions (Crise et al., 1999). The anti-estuarine circulation in the eastern basin caused by a rate of evaporation higher than the rate of precipitation, in conjunction with the very low terrestrial inputs since the construction of Aswan dam in Egypt in 1965, has created one of the most oligotrophic areas of the world (Azov, 1991). Concentrations of dissolved nutrients in its deep waters are much lower than those in other oceans and when mixed into the surface layers they support very low primary productivity, with a deep chlorophyll maximum (DCM) deeper than $100 \mathrm{~m}$. The circulation

Published by Copernicus Publications on behalf of the European Geosciences Union. 
of the Eastern Mediterranean is complex with a number of basin-scale, sub-basin-scale and mesoscale structures where permanent recurrent and transient cyclonic and anticyclonic eddies are interconnected by jets and currents.

During the second phase (2003-2006) of the Mediterranean ocean Forecasting System Project (MFS) entitled Toward Environmental Predictions (MFSTEP) there were three main aims: a) the Near Real Time Observing system; b) the numerical forecasting systems at basin scale and for regional areas; c) the forecast products dissemination/exploitation system. One of the six major scientific/technological objectives was the "implementation of three-dimensional ecosystem models coupled to the forecasting system for future predictions of biochemical fluxes and state variables". Over the last few years the computing resources and numerical modelling systems have become mature enough to be used to address the ambitious task of reproducing, explaining and predicting the evolution of marine ecosystems and their response to the variability of physical forcing. Thus a generic Biogeochemical Flux Model (BFM) based on ERSEM III (Vichi et al., 2004) was developed and coupled with existing hydrodynamic models previously developed during the Mediterranean Ocean Forecasting System Pilot Project (MFSPP) (Pinardi et al., 2003). Considering that primary production processes particularly in oligotrophic systems are strongly linked to the variability in physical forcing, a correct representation of the current structures is an undisputable requirement if a trustworthy representation for the lower trophic levels is to be achieved. The accurate simulation of the spatial and temporal variability of the physical and biogeochemical characteristics of the Mediterranean marine ecosystem is a fully coupled coastal-open ocean problem requiring the solution of a fully three-dimensional density driven general circulation problem, together with the appropriate description of ecological and biogeochemical processes. The modelling of marine ecosystems lags behind the modelling of marine physics, as in contrast to the simulation of the atmosphere or the ocean where a basic description of the physics is provided by the Navier-Stokes equations of fluid dynamics (Gill, 1982), there is no basic set of equations that describe the ocean ecosystem. In addition robust hydrodynamic models and adequate computing resources are required. However in the past ten years significant progress has been made with a number of different hydrodynamic and biogeochemical numerical models of varying degrees of complexity, and resolution being developed and implemented in the Mediterranean.

In this work the coupling of the BFM with the Aegean Levantine Eddy Resolving MOdel (ALERMO) (Korres and Lascaratos, 2003) in the Eastern Mediterranean is described. First in Sect. 2.1 we give a general description of the different functional groups while selected differences with ERSEM are explored and discussed. Parameters values used are presented in corresponding tables. Model setup in terms of resolution, forcing etc is described in Sect. 2.2 Simulations are presented in Sect. 3 with a preliminary validation of the model against field data, in N. Aegean, NE Aegean west of Dardanelles and S. Aegean as these areas are relatively data rich. Additionally, comparison of model results with satellite images is also attempted even though there are open questions associated with this due to the oligotrophic characteristics of the ecosystem. Finally in Sect. 4 some concluding remarks are given.

\section{Model}

\subsection{Model description}

The ALERMO model (Korres and Lascaratos, 2003) based on the Princeton Ocean Model (POM) (Blumberg and Mellor, 1978; Blumberg and Mellor, 1987) has been extensively described in the literature and is accompanied by a comprehensive user's guide (Mellor, 1998). It is a primitive equation, 3D model, with a bottom following vertical sigma coordinate system, a free surface and a split mode time step while temperature, salinity, velocity and surface elevation are prognostic variables.

An important factor in the system of the Eastern Mediterranean is the inflow of brackish and fresh waters from the Dardanelles and several major riverine systems respectively. In particular brackish waters (approximately $300 \mathrm{~km}^{3} / \mathrm{y}$ ) entering the Aegean from the Dardanelles are considered to strongly affect the dynamics of North and Central Aegean (Lykousis et al., 2002). Additionally the input of the main Greek rivers (Evros, Aliakmonas, Nestos and Axios) (Skoulikidis, 1993) although much smaller than the Dardanelles outflow ( $\sim 19 \mathrm{~km}^{3} / \mathrm{y}$ ) (Polat and Tugrul, 1996; Tugrul et al., 2002), is considered to make a substantial contribution towards a more productive system in the North Aegean. The Nile on the north coast of Africa $\left(\sim 63 \mathrm{~km}^{3} / \mathrm{y}\right.$ influx of fresh waters) (Abdel-Hamid et al., 1992) also constitutes a biologically significant riverine system.

ALERMO includes the parameterisation of both the Dardanelles and the major riverine systems. The net inflow into the Aegean from Dardanelles is roughly $10^{4} \mathrm{~m}^{3} / \mathrm{s}$ with a seasonal modulation of $5 \times 10^{3} \mathrm{~m}^{3} / \mathrm{s}$. Maximum values are reached during mid-July and minimum values during midJanuary with a constant salinity of 28.3 psu. The three Greek rivers are set according to daily climatological values provided by the Greek Ministry of Agriculture, ranging from 28 to $324 \mathrm{~m}^{3} / \mathrm{s}$, with maximum values during February and minimum values during July. As already mentioned the salinity at Dardanelles is set to $28.3 \mathrm{psu}$ and for the rivers to 0 . The temperature of the inflows is set at the same values with the model's top layer at the specified grid point. Although this parameterisation might produce an underestimation compared to a lateral flux boundary condition, the absence of detailed data on inflow and outflow velocities at the straits renders it the only possible approach. 
The coupling between the physics and the biology is done through advection-diffusion equations:

$$
\begin{aligned}
& \frac{\partial C}{\partial t}=-U \frac{\partial C}{\partial x}-V \frac{\partial C}{\partial y}-W \frac{\partial C}{\partial z}+\frac{\partial}{\partial x}\left(A_{H} \frac{\partial C}{\partial x}\right)+ \\
& \frac{\partial}{\partial y}\left(A_{H} \frac{\partial C}{\partial y}\right)+\frac{\partial}{\partial z}\left(K_{H} \frac{\partial C}{\partial z}\right)+\sum B F
\end{aligned}
$$

where $U, V, W$ the velocity field components, $A_{H}$ the horizontal viscosity coefficient, and $K_{H}$ the vertical eddy mixing coefficient, provided by POM. The last term accounts for the total biogeochemical flux, for each biogeochemical state variable. Along the open boundary the ecosystem pelagic state variables are described by solving water column 1-D ecosystem models at each grid point on the open boundary. Following the work of Skoulikidis (1993) on the N. Aegean rivers, Polat and Tugrul (1996) and Tugrul et al. (2002) for Dardanelles and Abdel-Hamid et al. (1992) for river Nile, the model was forced with annual mean nutrient, Particulate Organic Matter (POM) and dissolved Organic Matter (DOM) concentrations.

The BFM (Vichi et al., 2007) is a continuation of the generic highly complex model ERSEM (Baretta et al., 1995) and in particular in its last version ERSEM III. Although a detailed description of the BFM and its components is beyond the scope of this paper a short presentation of the code, as well as the parameter values used in the Eastern Mediterranean, is given later. This is considered necessary as its modular structure in conjunction with the open source allows the inclusion or modification of the processes from the standard version. It will also be helpful for those not familiar with the model or for those interested in the specific parameterisation. As described many times the model includes physical, chemical and biological processes, displaying a coherent system behaviour. Unlike those models which utilise classifications based on genera or species assemblages, it makes use of a functional group approach no phylogenetic meaning - where each group is composed of many different species with common biogeochemical and /or ecological functions, separating the organisms according to their trophic level (producers, consumers and decomposers) and further subdivided on the basis of their trophic links and/or size (Fig. 1). Although within each trophic level the groups are subject to the same processes, differentiation is achieved through the different parameter values. All the important physiological (ingestion, respiration, excretion and egestion), and population (growth, migration and mortality) processes are included, and are described by fluxes of carbon and nutrients. Carbon is the basic unit cycled in the system, followed by macronutrients and oxygen, with each state variable having up to five vector components $(C, N, P, S i, C h l-a)$, with variable carbon/nutrients and carbon/chl- $a$ ratios.

The model state variables, together with the respective constituents and the notation used are given in Table 1. According to the food web matrix as modulated for the Eastern Mediterranean (Table 2) diatoms $(P 1)$ are preyed upon by omnivorous mesozooplankton (Z4), nano-phytoplankton

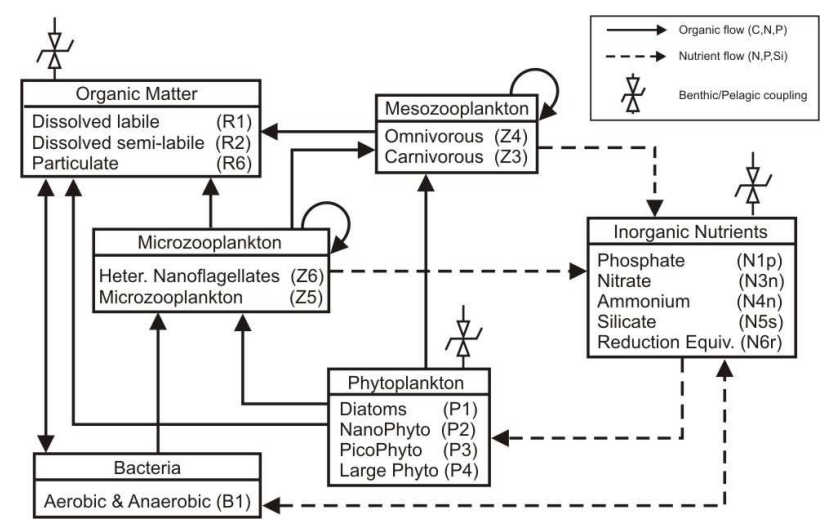

Fig. 1. Food web.

$(P 2)$ by heterotrophic nanoflagellates $(Z 6)$ and mostly by microzooplankton, pico-phytoplankton $(P 3)$ mostly by heterotrophic nanofalgellates and to a lesser extent by microzooplankton and finally large phytoplankton $(P 4)$ by omnivorous mesozooplankton. Bacteria $(B 1)$ consume DOC both labile and semi-labile ( $R 1$ and $R 2)$, act as decomposers on POC $(R 6)$ and compete with phytoplankton for inorganic nutrients. Their main predators are the heterotrophic nanoflagellates while a small part is also channelled to microzooplankton. Heterotrophic nanoflagellates are preyed upon by microzooplankton which in turn is eaten by omnivorous mesozooplankton. Omnivorous mesozooplankton is preyed upon by carnivorous mesozooplankton $(Z 3)$ which is the top predator in the food chain, while in all consumers $(Z 6, Z 5$, $Z 4, Z 3)$ there is feeding within the same functional group (cannibalism), acting as a stabilizing mechanism.

\subsubsection{Primary producers}

Phytoplankton comprise four groups with P1 and P4 representing cells with the same Equivalent Spherical Diameter (ESD) of 20-200 $\mu$, but with the former exhibiting an affinity for silica as diatoms do in natural conditions. $P 2$ have an ESD of $2-20 \mu$ and $P 3$ of $0.2-2 \mu$ representing nanophytoplankton and picophytoplankton respectively. All parameter values of this group are given in Tables 3 and 4 . The rate of change for each group can be described by the following text equation:

$\frac{d P}{d t}=$ photosynthesis-respiration-excretion-grazing

Gross photosynthetic production is modulated by maximum productivity rate ( $p_{-}$sum), temperature response (et), light limitation $(e i P I)$, and present biomass $(P I c)$. In the case of $P 1$ the external silicate concentration is also taken into account in a form of a limitation factor $(e N 5 s)$.

photosynthesis $=p \_s u m \times e t \times e N 5 s \times e i P I \times P I c$ 
Table 1. Pelagic state variables. Carbon and Chl units are in $\mathrm{mg} \mathrm{C} / \mathrm{m}^{3}$, nutrients are in $\mathrm{mmol} / \mathrm{m}^{3}$.

\begin{tabular}{lll}
\hline State variable & Symbol & Constituents \\
\hline Diatoms $(20-200 \mu \mathrm{m})$ & $P 1$ & $C, N, P, S i, C h l$ \\
Nanophytoplankton $(2-20 \mu \mathrm{m})$ & $P 2$ & $C, N, P, S i, C h l$ \\
Picophytoplankton $(0.2-2 \mu \mathrm{m})$ & $P 3$ & $C, N, P, S i, C h l$ \\
Large phyto $(20-200 \mu \mathrm{m})$ & $P 4$ & $C, N, P, S i, C h l$ \\
Pelagic bacteria & $B 1$ & $C, N, P$ \\
Heterotrophic nanoflagellates $(2-20 \mu \mathrm{m})$ & $Z 6$ & $C, N, P$ \\
Microzooplankton $(20-200 \mu \mathrm{m})$ & $Z 5$ & $C, N, P$ \\
Mesozooplankton (omnivorous) & $Z 4$ & $C, N, P$ \\
Mesozooplankton (carnivorous) & $Z 3$ & $C, N, P$ \\
DOM labile & $\mathrm{R} 1$ & $\mathrm{C}$ \\
DOM carbohydrates & $R 2$ & $C, N, P, S i$ \\
POC & $R 6$ & $C, N, P, S i$ \\
Nitrate & $N 3 n$ & $N$ \\
Ammonium & $N 4 n$ & $N$ \\
Phosphate & $N 1 p$ & $P$ \\
Silicate & $N 5 s$ & $S i$ \\
Reduction equivelants & $N 6 r$ & $S$ \\
Oxygen & $O 2 o$ & $\mathrm{O}_{2}$ \\
\hline
\end{tabular}

Table 2. Food matrix.

\begin{tabular}{lllll}
\hline Preys $\backslash$ Predators & $Z 6$ & $Z 5$ & $Z 4$ & $Z 3$ \\
\hline$P 1$ & 0.0 & 0.0 & 1.0 & 0.0 \\
$P 2$ & 0.2 & 1.0 & 0.4 & 0.0 \\
P3 & 1.0 & 0.1 & 0.0 & 0.0 \\
P4 & 0.0 & 0.0 & 1.0 & 0.0 \\
B1 & 1.0 & 0.1 & 0.0 & 0.0 \\
$Z 6$ & 0.2 & 1.0 & 0.0 & 0.0 \\
$Z 5$ & & 1.0 & 1.0 & 0.0 \\
$Z 4$ & & & 1.0 & 1.0 \\
$Z 3$ & & & & 1.0 \\
\hline
\end{tabular}

Although $P 1$ and $P 4$ are considered as having the same size the latter have a lower maximum productivity rate as shown in Table 4. The temperature response is the same for all groups and has an exponential form.

$e t=e^{\left(\log \left(p_{-} q 10\right) \times \frac{E T W-B A S E T E M P}{B A S E T E M P}\right)}$

where $p_{-} q 10$ is the characteristic temperature coefficient of each group indicating a doubling of reaction rate with a $10^{\circ} \mathrm{C}$ increase of the ambient temperature $(E T W)$ relative to the reference temperature (BASETEMP). The choice of the reference temperature value is of particular importance as the value used in the North Sea $\left(10^{\circ} \mathrm{C}\right)$ is well below the reference temperature of the productive layer of the Eastern Mediterranean. The BFM formulation has a smaller gradient than ERSEM III as shown in Fig. 2, which is further decreased with higher reference values.

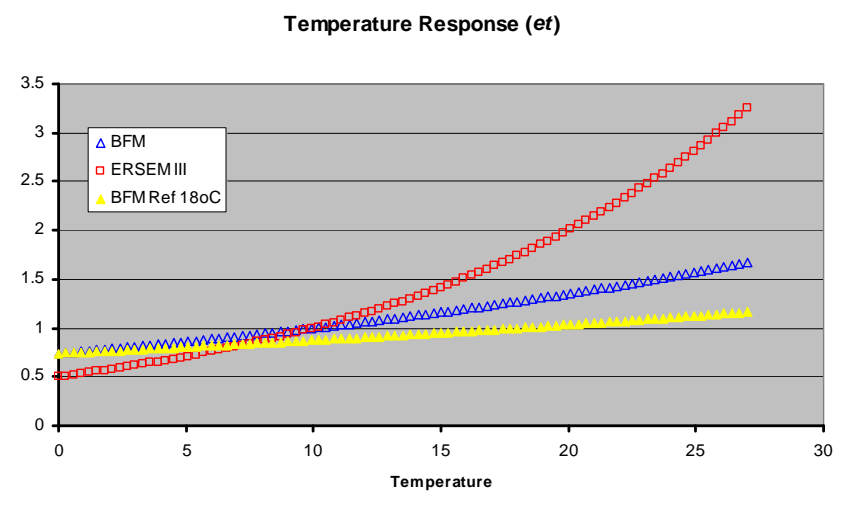

Fig. 2. Temperature response in BFM with standard reference temperature $\left(10^{\circ} \mathrm{C}\right)$ and Eastern Mediterranean reference temperature $\left(18^{\circ} \mathrm{C}\right)$ and ERSEM III $\left(10^{\circ} \mathrm{C}\right)$.

Light limitation is computed according to the relation:

$e i P I=1-e^{\left(-\frac{q c h l P c \times p \_a l p h a \_c h l}{p \_s u m \times e t \times e N 5 s \times I r r}\right)}$

where $q c h l P c$ is the $\mathrm{Chl}: \mathrm{C}$ ratio, $p \_a l p h a_{-} c h l$ the initial slope of the $P-I$ curve, and $I r r$ the photosynthetic irradiance parameterised according to the Lambert-Beer formulation with extinction coefficients (in addition to the background) for suspended particles, silt, and phytoplankton shelf shading.

Silicate limitation is a function of the external dissolved silicate concentration $N 5 s$ where $p_{-} c h P s$ is the half saturation constant of silicate in the water.

$e N 5 s=\frac{N 5 s}{N 5 s+p_{-} \operatorname{ch} P s}$ 
Table 3. Optical parameters.

\begin{tabular}{lll}
\hline Parameter & Symbol & Value \\
\hline Background extinction coefficient $\left(\mathrm{m}^{-1}\right)$ & $p_{\text {eepsO }}$ & 0.04 \\
Extinction coefficient of silt $\left(\mathrm{m}^{-1} \mathrm{mg}^{-1}\right)$ & $p_{\text {eepsESS }}$ & $0.04 \mathrm{e}^{-3}$ \\
Extinction coefficient of phyto $\left(\mathrm{m}^{-1} \mathrm{mgC}^{-1}\right)$ & $p_{\text {eepsChla }}$ & $10.0 \mathrm{e}^{-3}$ \\
Extinction coefficient of POC $\left(\mathrm{m}^{-1} \mathrm{mgC}^{-1}\right)$ & $p_{-}$epsR6 & $0.1 \mathrm{e}^{-3}$ \\
Proportion of irradiance photosynthetically available & p_PAR & 0.5 \\
Adaptation depth $(\mathrm{m})$ & paddepth & 10 \\
\hline
\end{tabular}

Table 4. Parameters for the primary producers.

\begin{tabular}{|c|c|c|c|c|c|}
\hline Parameter & Symbol & $P 1$ & $P 2$ & $P 3$ & $P 4$ \\
\hline Characteristic Q10 & p_q10 & 2.0 & 2.0 & 2.0 & 2.0 \\
\hline Max. productivity at $10^{\circ} \mathrm{C}\left(\right.$ day $\left.^{-1}\right)$ & p_sum & 2.5 & 3.0 & 3.5 & 1.5 \\
\hline Rest respiration at $10^{\circ} \mathrm{C}\left(\right.$ day $\left.^{-1}\right)$ & p_srs & 0.1 & 0.05 & 0.1 & 0.1 \\
\hline Activity respiration (fraction of production) & p_pu_ra & 0.1 & 0.1 & 0.2 & 0.1 \\
\hline Activity excretion (fraction of production) & p_pu_ea & 0.05 & 0.1 & 0.1 & 0.15 \\
\hline Redfield N/C ratio (mmol N/mgC) & p_qnRc & 0.0126 & 0.0126 & 0.0126 & 0.0126 \\
\hline Redfield $\mathrm{P} / \mathrm{C}$ ratio (mmol P/mgC) & p_qpRc & $0.786 \mathrm{e}-3$ & $0.786 \mathrm{e}-3$ & $0.786 \mathrm{e}-3$ & $0.786 \mathrm{e}-3$ \\
\hline Redfield $\mathrm{Si} / \mathrm{C}$ ratio (mmol Si/mgC) & p_qsRc & 0.01 & 0.0 & 0.0 & 0.0 \\
\hline Mult. Factor Max. N/C ratio & p_xqn & 2.0 & 2.0 & 2.0 & 2.0 \\
\hline Mult. Factor Max. P/C ratio & p_xqp & 2.0 & 2.0 & 2.0 & 2.0 \\
\hline Min. N/C ratio (mmol N/mgC) & p_qnlc & 0.00687 & 0.00687 & 0.00687 & 0.00687 \\
\hline Min. P/C ratio (mmol P/mgC) & p_qplc & $0.4288 \mathrm{e}-3$ & $0.4288 \mathrm{e}-3$ & $0.4288 \mathrm{e}-3$ & $0.4288 \mathrm{e}-3$ \\
\hline Min. $\mathrm{Si} / \mathrm{C}$ ratio $(\mathrm{mmol} \mathrm{Si} / \mathrm{mgC})$ & p_qslc & 0.007 & 0.0 & 0.0 & 0.0 \\
\hline Uptake parameter for $\mathrm{N}\left(\mathrm{m}^{3} / \mathrm{mgC}\right.$ day) & p_qun & 0.0025 & 0.0025 & 0.0025 & 0.0025 \\
\hline Uptake parameter for $\mathrm{PO}_{4}\left(\mathrm{~m}^{3} / \mathrm{mgC}\right.$ day $)$ & p_qup & 0.0025 & 0.0025 & 0.0025 & 0.0025 \\
\hline Uptake parameter for $\mathrm{SiO}_{4}\left(\mathrm{~m}^{3} / \mathrm{mgC}\right.$ day $)$ & p_qus & 0.0025 & 0.0 & 0.0 & 0.0 \\
\hline Nutrient stress sinking threshold & p_esNI & 0.70 & 0.75 & 0.75 & 0.75 \\
\hline Background sinking rate (m/day) & p_rPim & 0.25 & 0.0 & 0.0 & 0.25 \\
\hline Nutrient stress sinking (m/day) & p_res & 5.0 & 0.0 & 0.0 & 3.0 \\
\hline Half value of $\mathrm{SiO}_{4}$ limitation $\left(\mathrm{mmol} \mathrm{Si} / \mathrm{m}^{3}\right)$ & p_chPs & 1.0 & 0.0 & 0.0 & 0.0 \\
\hline Half value of $\mathrm{NO}_{3}$ uptake $\left(\mathrm{mmol} \mathrm{N} / \mathrm{m}^{3}\right)$ & p_1N4 & 1.0 & 0.5 & 0.1 & 1.0 \\
\hline Max chl to carbon ratio (mgChl/mgC) & p_qchlc & 0.05 & 0.03 & 0.07 & 0.02 \\
\hline Slope of $P-I$ curve $\left(\mathrm{W} \mathrm{m}^{-2}\right)^{-1} \mathrm{~d}^{-1}$ & p_alpha_chl & $1.38 \mathrm{e}^{-5}$ & $1.52 \mathrm{e}^{-5}$ & $1.52 \mathrm{e}^{-5}$ & $1.38 \mathrm{e}^{-5}$ \\
\hline Chlorophyll destruction factor & p_sdchl & 0.2 & 0.2 & 0.2 & 0.2 \\
\hline
\end{tabular}

Respiration has two parts, the basal which is independent of growth modulated by the biomass, the temperature response (et) and the specific constant respiration rate ( $\left.p_{-} s r s\right)$, and the activity respiration. The latter is a constant fraction $\left(p_{-} p u_{-} r a\right)$ of the assimilated carbon i.e. photosynthesis-excretions. It is due to the basal respiration that under low light conditions the net primary production can become negative.

$$
\begin{aligned}
& \text { respiration }=(\overbrace{e t \times p \_s r s \times P I c}^{\text {BASAL }})+ \\
& (\overbrace{p_{-} p u_{-} r a \times(\text { photosynthesis }- \text { excretions })}^{\text {ACTIVITY }})
\end{aligned}
$$

The process of nutrient stress lysis in ERSEM III has been replaced with the excretion of dissolved carbohydrates. Gross photosynthetic production is not dependent on the external nutrient supply (with the exception of silica for diatoms), 


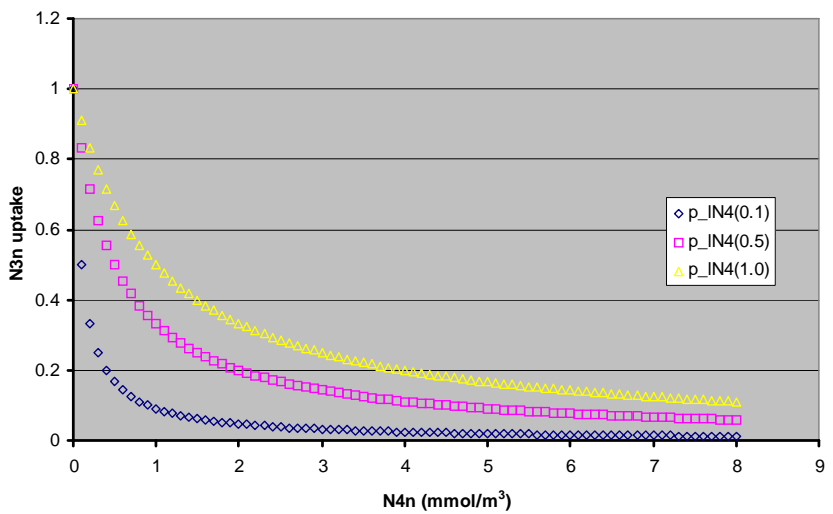

Fig. 3. Uptake preference for nitrate.

which means that the cell can produce carbon even at very low nutrient concentrations. Thus a fixed proportion of the carbon ( $\left.p_{-} p u_{-} e a\right)$ produced is channelled to dissolved carbohydrates $(R 2)$

excretion $=$ photosynthesis $\times p_{-}$pu_ea

while the rest can be assimilated or excreted according to the actual nutrient uptake and the minimum internal nutrient/carbon ratio ( $\left.p_{-} q n l c, p_{-} q p l c\right)$.

The grazing term refers to zooplankton predation analysed later in the paper with the flux to each predator mainly controlled by the food matrix thus increasing the generic nature of the model.

Nutrient uptake (uptake total $_{\text {) }}$ is constrained between the maximum possible uptake for the present biomass (uptake $_{\max }$ ) and the required uptake which is the sum of the uptake due to net production (uptake netprod$_{\text {) }}$ and the uptake necessary to cover internal shortages (uptake miss $_{\text {) }}$.

uptake $_{\text {total }}=\min \left(\right.$ uptake $_{\max },\left(\right.$ uptake $_{\text {netprod }}+$ uptake $\left.\left._{\text {miss }}\right)\right)$

The maximum possible uptake (uptake $\max$ ) is a function of external nutrient concentration, the present biomass (PIc) and the uptake parameter ( $\left.p_{-} q u n\right)$ for the specific nutrient (Aksnes and Egge, 1991) and is a measure for the cell of the trophic status of the surrounding water. In the case of nitrogen there is also a partition between nitrate $(N 3 n)$ and ammonium $(N 4 n)$.

uptake $_{\max }=(\overbrace{\left.p_{-q u n \times N 3 n \times P I c \times\left(\frac{p \_l N 4}{p \_l N 4+N 4 n}\right)}^{\text {uptake }_{\text {max_N3n }}^{\text {an }}}\right)}^{\text {. }})$

$+(\overbrace{p_{-q u n} \times N 4 n \times P I c}^{\text {uptake }_{\text {max_N4n }}})$

The half saturation value ( $\left.p \_l N 4\right)$ controls the nitrate uptake with small cells ( $p \_l N 4=0.1$ ) having a preference for ammonium as shown in Fig. 3.
The uptake due to net production (uptake ${ }_{\text {netprod }}$ ) is regulated by the productivity (photosynthesis - respiration - excretion).

uptake $_{\text {netprod }}=$ productivity $\times p_{\_} x q n \times p_{\_} q n R c$

where $p_{-} q n R c$ the Redfield N/C ratio and $p_{-} x q n$ the multiplication factor account for higher uptake compared to carbon (luxury uptake).

The missing nutrient uptake (uptake miss $_{\text {) }}$ is a function of the maximum internal Nutrient/Carbon ratio having subtracted the structural part (PIn) multiplied with the net growth rate, a representation of an adaptation mechanism to the current conditions (sadap).

uptake $_{\text {miss }}=\left(p \_x q n \times p_{-} q n R c \times P I c-P I n\right) \times$ sadap

If the uptake is $+v e$ then the nitrogen flow into the cell is partitioned between nitrate and ammonium

$$
\begin{aligned}
\text { uptake }_{N 3 n} & =\frac{\text { uptake }_{\text {total }} \times \text { uptake }_{\max \_N 3 n}}{\text { uptake }_{\max }} \\
\text { uptake }_{N 4 n} & =\frac{\text { uptake }_{\text {total }} \times \text { uptake }_{\max \_N 4 n}}{\text { uptake }_{\text {max }}}
\end{aligned}
$$

while if the internal nitrogen exceeds the maximum internal ratio the uptake becomes - ve and the surplus is excreted in the form of ammonium.

The same processes are used for phosphorus and silicate but in the latter there is no internal storage and thus uptake is dependent on the appropriate Redfield ratio $\left(p_{-} q s R c\right)$.

In the early versions of ERSEM (I and II) chlorophyll was a diagnostic variable calculated from the cell carbon content with an assumed constant ratio. Although this simplification in the first steps of the model could be justified, the significant variability of C/chl ratio (23-79) (Parsons et al., 1973) forced for an upgrade in ERSEM III with the introduction of chlorophyll as a state variable (Phytoi) (Vichi et al., 2007). Using the same parameterisation in BFM chlorophyll synthesis is controlled by the productivity (photosynthesis - respiration - excretion), the maximum $\mathrm{Chl} / \mathrm{C}$ ratio (rho_Chl) which incorporates a light acclimation following Geider et al. (1998) and the intracellular nitrogen limitation factor $(i N I n)$, while there is also a turnover/destruction term.

rate_chl $=i N I n \times r h o \_C h l \times$ productivity-destruction

The maximum $\mathrm{Ch} / \mathrm{C}$ ratio is calculated as:

$r h o \_C h l=\frac{p_{-} q c h l c \times \text { photosynthesis } \times P I c}{p_{-} \text {alpha_chl } \times(\text { phytoi }+1) \times I r r}$

where $\left(p_{-} q c h l c\right)$ is the maximum $\mathrm{Chl} / \mathrm{C}$ ratio for each group.

The intracellular nitrogen limitation factor is constrained between the range $0-1$ and follows Droop kinetics Droop (1974). It is a function of the actual internal cell $\mathrm{N} / \mathrm{C}$ ratio $(q n P c)$ and the Redfield ratio $\left(p_{-} q n R c\right)$ having subtracted the structural content of the cell (minimum N/C ratio) (p_qnlc).

$i N I n=\min \left(1.0, \max \left(0.0, \frac{q n P c-p_{-q n l c}}{p_{-} q n R c-p_{\_} q n l c}\right)\right)$ 
Table 5. Parameters for the decomposers and the detritus.

\begin{tabular}{|c|c|c|}
\hline Parameter & Symbol & $B 1$ \\
\hline Characteristic Q10 & p_q10 & 2.95 \\
\hline Half saturation of $\mathrm{O}_{2}\left(\mathrm{mmol} / \mathrm{m}^{3}\right)$ & p_chdo & 30.0 \\
\hline Max. productivity at $10^{\circ} \mathrm{C}\left(\right.$ day $\left.^{-1}\right)$ & p_sum & 8.38 \\
\hline Rest respiration at $10^{\circ} \mathrm{C}\left(\right.$ day $\left.^{-1}\right)$ & p_srs & 0.01 \\
\hline Decrease in assimilation efficiency at low $\mathrm{O}_{2}$ conc. & p_puo & 0.2 \\
\hline Assimilation efficiency & p_pu & 0.4 \\
\hline Mortality factor & P_sd & 0.0 \\
\hline Redfield N/C ratio (mmol N/mgC) & p_qne & 0.017 \\
\hline Redfield $\mathrm{P} / \mathrm{C}$ ratio (mmol P/mgC) & p_qpc & 0.0019 \\
\hline Min. N/C ratio (mmol N/mgC) & p_qlnc & 0.0085 \\
\hline Min. $\mathrm{P} / \mathrm{C}$ ratio $(\mathrm{mmol} \mathrm{P} / \mathrm{mgC})$ & p_qlpc & $0.95 \mathrm{e}-3$ \\
\hline Uptake parameter for $\mathrm{NO}_{3}$ and $\mathrm{NH}_{4}\left(\mathrm{~m}^{3} / \mathrm{mgC}\right.$ day $)$ & p_qun & 0.05 \\
\hline Uptake parameter for $\mathrm{PO}_{4}\left(\mathrm{~m}^{3} / \mathrm{mgC}\right.$ day $)$ & p_qup & 0.005 \\
\hline Half value of $\mathrm{NO}_{3}$ uptake & p_lN4 & 0.05 \\
\hline Preference for DOC $\left(\right.$ day $\left.^{-1}\right)$ & p_suR1 & 0.5 \\
\hline Preference for DOC (sugars) $\left(\right.$ day $\left.^{-1}\right)$ & p_suR2 & 0.025 \\
\hline Preference for POC $\left(\right.$ day $\left.^{-1}\right)$ & p_suR6 & 0.1 \\
\hline Detritus sinking rate (m/day) & p_rR6m & 3.0 \\
\hline Relative nitrification rate $\left(\right.$ day $\left.^{-1}\right)$ & p_sN4N3 & 0.01 \\
\hline Relative nitrification rate at $10^{\circ} \mathrm{C}$ & p_q10N4N3 & 2.367 \\
\hline Relative denitrification rate $\left(\right.$ day $\left.^{-1}\right)$ & p_sN3O4n & 0.35 \\
\hline Relative reoxidation rate of reduction equivalents $\left(\right.$ day $\left.^{-1}\right)$ & p_rOS & 0.05 \\
\hline Relative regeneration rate of dissolved silica $\left(\right.$ day $\left.^{-1}\right)$ & p_sR6N5 & 0.1 \\
\hline Relative regeneration rate of dissolved silica at $10^{\circ} \mathrm{C}$ & p_q10R6N5 & 1.49 \\
\hline Oxygen half saturation regulating factor $\left(\mathrm{mmol} / \mathrm{m}^{3}\right)$ & p_clO2o & 10.0 \\
\hline
\end{tabular}

Intracellular limitation factors are calculated accordingly for phosphorus and silicate while in this particular application for the total limitation factor the Liebig rule is used (min).

Finally sedimentation of phytoplankton is the product of a background sinking parameter ( $p_{\_} r$ Pim) and the sinking due to nutrient-limited conditions according to a threshold value ( $\left.p_{-} e s N I\right)$, the total nutrient limitation factor $(t N)$, and the sedimentation rate parameter ( $\left.p_{-} r e s\right)$. In this way the phytoplankton can move from a nutrient-limited area to an area where nutrients exist, a significant process in patchy systems such as the Eastern Mediterranean basin.

sedimentation $=\overbrace{p_{p \_ \text {Pim }}}^{\text {Background }}+$

NutrientLimitation

$\overbrace{p \_r e s \times \max \left(0.0,\left(p_{\_} e s N I-t N\right)\right)}$

The total nutrient limitation factor $(t N)$ is calculated by the intracellular nitrogen (INin) and phosphorus (INIp) (also silicate for diatoms) limitation factors with a triple user choice. Thus the first is the root of the multiplied limitations, the second takes the most limiting nutrient (used in this application) and the third considers a ratio of the two.

\subsubsection{Decomposers}

Although at the beginning of ERSEM there were only bacteria filling the role of decomposers (Baretta-Bekker et al., 1995), significant changes were introduced in subsequent versions (Allen et al., 2004; Baretta-Bekker et al., 1997; Blackford et al., 2004; Vichi et al., 2004). In BFM pelagic bacteria ( $B 1)$ (Table 5) are a wide group comprising free living heterotrophic bacteria utilizing dissolved $(R 1)$ and particulate $(R 6)$ detritus under both aerobic and anaerobic processes.

The bacterial rate of change is described by the following text equation,

$\frac{d B}{d t}=$ uptake - respiration - mortality - predation

Actual uptake is constrained between the potential uptake (uptake $_{\text {pot }}$ ) and the total available substrate (uptake sub $_{\text {) }}$

uptake $=\min \left(\right.$ uptake $_{\text {pot }}$, uptake $\left._{\text {sub }}\right)$

Potential uptake represents the intrinsic potential for growth under the present environmental conditions and is a function of maximum productivity rate (p_sum), temperature 


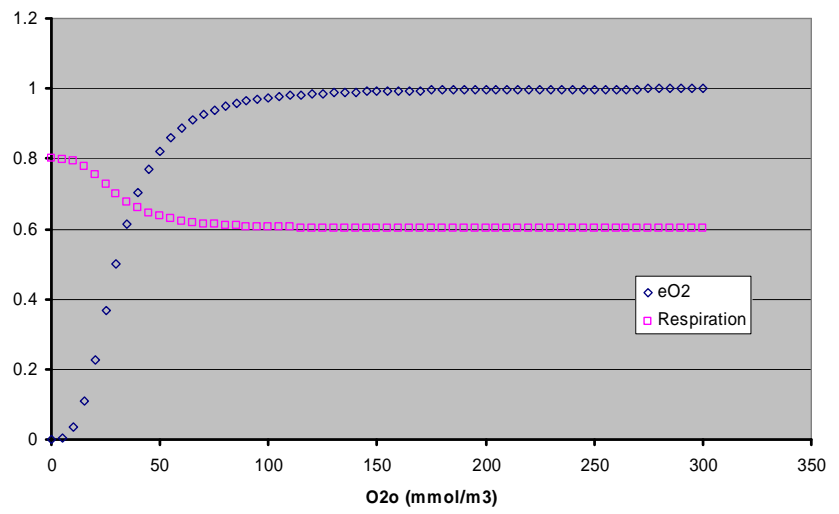

Fig. 4. Oxygen factor (eO2) and activity respiration rate.

response (et), intracellular nutrient limitation $(i N)$, and present biomass $(B 1 c)$.

uptake $_{\text {pot }}=p \_s u m \times i N \times e t \times B 1 c$

nutrient limitation is constrained between the range $0-1$ and unlike phytoplankton is a function of the actual internal cell $\mathrm{N} / \mathrm{C}$ ratio $(q n B 1 c)$ and the Redfield ratio $\left(p_{-} q n c\right)$, (in this case for nitrogen) without considering the structural component.

$i N I n=\min \left(1.0, \max \left(0.0, \frac{q n B 1 c}{p_{-} q n c}\right)\right)$

The total limitation $(i N)$ also follows the Liebig rule for nitrogen and phosphorus.

The uptake due to substrate represents the available food and is separated among the different food sources. Both available labile DOM $(R 1)$ and carbohydrates $(R 2)$ are taken up according to the preference factors $p_{\lrcorner} s u R 1$ and $p_{\lrcorner} s u R 2$ respectively, while for the particulate component of detritus (R6) apart from the preference ( $\left.p_{\lrcorner} s u R 6\right)$, the quality is also taken into consideration (suR6).

uptake $_{\text {sub }}=R 1 c \times p_{\_} s u R 1+R 2 c \times p_{\lrcorner} s u R 2$

$+R 6 c \times p s u R 6 \times s u R 6$

where suR6 is a factor of the most limited nutrient inside the available detritus, and is a function of the internal N/C and $\mathrm{P} / \mathrm{C}$ ratios and the Redfield ratio for bacteria.

$s u R 6=\min \left(\min \left(1.0, \frac{q n R 6 c}{p_{-} q n c}\right), \min \left(1.0, \frac{q p R 6 c}{p_{-} q p c}\right)\right)$

Respiration is partitioned between basal which is formulated as in phytoplankton and activity respiration where a variable component has been introduced in order to differentiate between oxic and anoxic conditions.

respiration $=(\overbrace{e t \times p_{-} s r s \times B 1 c}^{\text {BASAL }})+$
$(\overbrace{\left(1.0-p_{-} p u+p_{-} p u o \times(1.0-e O 2)\right) \times \text { uptake }}^{\text {ACTIVITY }})$ where $p_{-} p u$ the assimilation efficiency under oxic conditions and $p_{-}$puo the decrease in assimilation efficiency under anoxic conditions. The oxygen factor is a cubic Michaelis - Menten relation, of the available oxygen $(O 2 o)$ and the oxygen concentration at which metabolic functionalities are halved $\left(p_{-} c h d o\right)$.

$e O 2=\frac{O 2 o^{3}}{O 2 o^{3}+p_{-} c h d o^{3}}$

This is a steep sigmoid curve giving an activity respiration value between 0.6 and 0.8 of the uptake (Fig. 4).

To partly account for viral lysis a mortality term is used with a constant mortality rate $\left(p_{-} s d\right)$ modulated by the temperature factor $(e t)$. Mortality is directed to the dissolved organic fraction $(R 1)$ for both carbon and nutrients.

mortality $=p_{\lrcorner} s d \times e t \times B 1 c$

A future improvement of the code will be the insertion of a density dependent mortality, which will account for the observed maximum bacterial biomass in the open ocean.

A much better but more complex approach will be the addition of a viral module since viruses are the most common biological agents in the sea (Fuhrman, 1999; Heldal and Bratbak, 1991; Proctor and Fuhrman, 1990; Suttle et al., 1990). Viruses can affect a large number of organisms influencing many biogeochemical and ecological processes including nutrient cycling, system respiration, particle size distribution and sinking rates, bacterial and algal biodiversity and species distributions, algal bloom control and genetic transfer (Bratbak et al., 1992; Fuhrman, 1999). The importance of this mechanism has been already illustrated through experimental simulations in ERSEM with the incorporation of a viral module. Results from these simulations indicated that when the bacteria were not limited by the availability of dissolved organic carbon, the virus acted to reduce bacterial production and enhance primary production. The ratio of primary to bacterial production changed from 4.83 without the virus, to 8.27 with the virus clearly demonstrating a shift away from a microbial loop dominated ecosystem. Conversely when the bacteria concerned were dissolved organic carbon limited, the virus acted to increase the turnover of dissolved organic carbon and to enhance bacterial production, thus driving the system towards an increase in primary production since enhanced dissolved nutrient cycling increased dissolved inorganic nutrient availability. Although the turnover of carbon was enhanced there was no change in the trophic status as indicated by the ratio of primary to bacterial production which had a value of 2.15 in both cases.

However in BFM predation on bacteria is exerted mainly by heterotrophic flagellates (Z6) and to a small degree by microzooplankton $(Z 5)$. Bacteria can act as remineralisers excreting nutrients or as competitors to phytoplankton taking up nutrients depending on their internal Nutrient/Carbon ratios. Therefore if the Nutrient/Carbon ratio of the food 
Table 6. Parameters for the consumers.

\begin{tabular}{|c|c|c|c|c|c|}
\hline Parameter & Symbol & Z6 & $Z 5$ & $Z 4$ & $Z 3$ \\
\hline Characteristic Q10 & p_q10 & 2.0 & 2.0 & 2.0 & 2.0 \\
\hline Half saturation of $\mathrm{O}_{2}\left(\mathrm{mmol} / \mathrm{m}^{3}\right)$ & p_chro & 7.8 & 7.8 & - & - \\
\hline Max. productivity at $10^{\circ} \mathrm{C}\left(\right.$ day $\left.^{-1}\right)$ & p_sum & 5.0 & 2.0 & 0.5 & 0.3 \\
\hline Rest respiration at $10^{\circ} \mathrm{C}\left(\right.$ day $\left.^{-1}\right)$ & p_srs & 0.02 & 0.02 & 0.02 & 0.01 \\
\hline Assimilation efficiency in microzoo & p_pu & 0.3 & 0.5 & - & - \\
\hline Assimilation efficiency in mesozoo & p_puI_u & - & - & 0.6 & 0.6 \\
\hline Activity excretion (fraction of production) & p_pu_ea & 0.5 & 0.5 & - & - \\
\hline Fraction of excretion passed to DOM & p_pe_R1 & 0.7 & 0.7 & - & - \\
\hline Excretion to POC (fraction of food eaten) & p_peI_R6 & - & - & 0.35 & 0.3 \\
\hline Oxygen dependent mortality $\left(\right.$ day $\left.^{-1}\right)$ & p_sdo & 0.05 & 0.05 & $0.4 \mathrm{e}-3$ & $0.4 \mathrm{e}-3$ \\
\hline Natural mortality $\left(\right.$ day $\left.^{-1}\right)$ & p_sd & - & - & 0.01 & 0.01 \\
\hline Density dependent mortality $\left(\right.$ day $\left.^{-1}\right)$ & p_sds & - & - & 2.0 & 2.0 \\
\hline Max. N/C ratio in microzoo ( $\mathrm{mmol} \mathrm{N} / \mathrm{mgC})$ & p_qn_mz & 0.0167 & 0.0167 & - & - \\
\hline Max. $\mathrm{P} / \mathrm{C}$ ratio in microzoo $(\mathrm{mmol} \mathrm{P} / \mathrm{mgC})$ & p_qp_mz & $0.185 \mathrm{e}-3$ & $0.185 \mathrm{e}-3$ & - & - \\
\hline $\mathrm{N} / \mathrm{C}$ ratio in mesozoo $(\mathrm{mmol} \mathrm{N} / \mathrm{mgC})$ & p_qnc & - & - & 0.015 & 0.015 \\
\hline $\mathrm{P} / \mathrm{C}$ ratio in mesozoo $(\mathrm{mmol} \mathrm{P} / \mathrm{mgC})$ & p_qpc & - & - & $0.167 \mathrm{e}-2$ & $0.167 \mathrm{e}-2$ \\
\hline Damping coefficient of excretion $\left(\right.$ day $\left.^{-1}\right)$ & p_stemp & 0.5 & 0.5 & - & - \\
\hline Half saturation food uptake $\left(\mathrm{mgC} / \mathrm{m}^{3}\right)$ & p_chuc & 50.0 & 50.0 & - & - \\
\hline Lower threshold for feeding $\left(\mathrm{mgC} / \mathrm{m}^{3}\right)$ & p_minfood & 30.0 & 30.0 & - & - \\
\hline Search volume $\left(\mathrm{m}^{3}\right)$ & p_vum & 0.016 & 0.032 & - & - \\
\hline
\end{tabular}

(dissolved and particulate) exceeds the Redfield ratio ( $p_{-} q n c$ or $\left.p_{-} q p c\right)$ then there is excretion to ammonium $(N 4 n)$ or to phosphate $(N 1 p)$ according to the present biomass and the net productivity rate.

excretion $=$ productivity $_{\text {rate }} \times$

$$
\left(\frac{r u R 6 n+r u R 1 n}{\text { uptake }}-p_{-} q n c\right) \times B 1 c
$$

If the food is of low quality then there is uptake of inorganic nutrients.

Nutrient uptake (in this case for $\mathrm{N}$ ) is separated into maximum uptake which is filling an empty cell $(B 1 c)$ according to the characteristic uptake parameter ( $\left.p_{-} q u n\right)$ and the external nutrient concentration $(N 3 n)$ with the same differentiation as in phytoplankton between nitrate and ammonium.

uptake $_{\max }=(\overbrace{\left.p_{-q u n \times N 3 n \times B 1 c \times\left(\frac{p_{\_} l N 4}{p_{-} l N 4+N 4 n}\right)}^{\text {uptake }_{\text {max }}{ }_{\text {N33n }}}\right)}^{\text {. }})$

$+(\overbrace{p_{-} q u n \times N 4 n \times B 1 c}^{\text {uptake }_{\text {max_N4n }}})$

\subsubsection{Consumers}

Consumers are represented by two major groups, the microzooplankton composed of heterotrophic nanoflagellates and microzooplankton, and the mesozooplankton which is divided into omnivorous and carnivorous mesozooplankton. The text equation describing the rate of change is:

$\frac{d Z}{d t}=$ uptake-respiration - mortality - excretion - predation

Uptake is a function of maximum growth rate ( $p_{-}$sum), temperature response (et), the available food (efood) and the standing stock $($ ZIc $)$.

uptake $=p \_$sum $\times$et $\times$efood $\times Z I c$

For the available food a Michaelis - Menten relation is used, considering the total available food sources (rumc) - calculated by the available stocks and the food matrix preference factor including a lower threshold parameter ( $p$ _minfood $)$ in order to avoid overexploitation and the half saturation parameter $\left(p_{\text {_chuc }}\right)$ where food uptake is 0.5 of maximum.

efood $=\frac{\text { rumc }}{\text { rumc }+p_{\_} \text {chuc }}$

In the case of mesozooplankton the Michaelis - Menten relation is modulated by a search volume parameter ( $p_{-}$vum), the total available food (ZIm) and the maximum growth rate (p_sum) while there is no lower threshold parameter constraining ZIm.

efood $=\frac{p_{-} v u m \times Z i m}{p_{-} v u m \times Z i m+p_{-} \text {sum }}$ 
Once the actual uptake is estimated the contribution of each food source is calculated according to the ratio of uptake/total available food (rumc or ZIm).

Respiration has two components, the temperature - dependent basal respiration and the activity respiration.

$$
\begin{aligned}
& \text { respiration }=(\overbrace{e t \times p_{-} s r s \times Z I c}^{\text {BASAL }})+ \\
& (\overbrace{\left(\left(1.0-p_{-} p u\right) \times\left(1.0-p_{-} p u_{-} e a\right)\right) \times \text { uptake }}^{\text {ACTIVITY }})
\end{aligned}
$$

where $p$-srs the characteristic rest respiration rate of the particular functional group, $p_{-} p u$ the assimilation efficiency and p_pu_ea the excreted fraction of uptake.

Mortality is handled differently between microzooplankton and mesozooplankton with the former group being coupled to the oxygen regime. Thus the constant background mortality rate $\left(p_{-} s d\right)$ is increased according to the oxygen conditions, modulated by a low oxygen mortality rate ( $p_{-} s d o$ ) and an oxygen limitation factor (eO2) calculated from the relative oxygen saturation and a half saturation parameter.

mortality $=\left((1.0-e O 2) \times p_{\lrcorner} s d o+p_{\lrcorner} s d\right) \times Z I c$

Mesozooplankton mortality is composed of the natural mortality affected by temperature and the density - dependent mortality modulated by a constant low oxygen mortality rate ( $p_{\lrcorner} s d o$ ) and a density - dependent mortality ( $\left.p_{\lrcorner} s d s\right)$ term.

mortality $=(\overbrace{p_{\lrcorner} s d \times e t \times Z I c}^{\text {NATURAL }})+(\overbrace{p_{\lrcorner s d o \times Z I c^{p \_s d s}}^{\text {DENSITYDEPENDENT }}})$

Excretion is a function of the assimilation efficiency ( $\left.p_{-} p u\right)$ of each group and the excreted fraction of uptake ( $\left.p p u \_e a\right)$.

excretion $=$ uptake $\times\left(1.0-p_{-} p u\right) \times p_{-} p u_{-} e a$

The mortality and excretion products in the case of microzooplankton are apportioned between dissolved and particulate detrital components according to a parameter ( $\left.p_{-} p e_{-} R l\right)$ with the highest proportion towards DOM. For mesozooplankton excretion is a fraction of the total food uptake ( $p_{-}$peI_R6) while all products are directed to the particulate detrital pool.

Nutrient uptake is through feeding according to the nutrient to carbon ratio of each food prey. The same approach is used in the excretions with nutrient being coupled to carbon following the internal nutrient to carbon ratio. To avoid excess nutrients being built up inside the consumer pools, any amounts higher than the maximum allowed nutrient to carbon ratios $\left(p_{-} q n \_m z\right)$ are excreted to the inorganic pool (phosphate and ammonium) according to a dumping coefficient (p_stemp).
Summarizing the above described processes, the dissolved organic matter $(R 1)$ is produced by all groups except mesozooplankton and is consumed by bacteria while the particulate fraction $(R 6)$ is produced by all groups except bacteria which are the sole consumers. The semi-labile carbohydrates $(R 2)$ produced during phytoplankton limitation are exclusively used by bacteria. Water column processes such as nitrification, denitrification, reoxidation of reduction equivalents and regeneration of dissolved silica are all included in the model, and are functions of water temperature and the appropriate parameters (Table 5).

\subsection{Model set-up}

The ALERMO hydrodynamic model has a horizontal resolution of $1 / 10^{\circ} \times 1 / 10^{\circ}, 24$ sigma layers in the vertical and an open boundary at $20^{c}$ 。 E. In order to have a better representation of the biological processes near the surface and a realistic surface and bottom boundary layer, a logarithmic distribution in the vertical layers has been chosen near the surface and the bottom. The model bathymetry was constructed from the US Navy Digital Bathymetric Data Base $5\left(1 / 12^{\circ} \times 1 / 12^{\circ}\right)$ using linear interpolation for the mapping of the data onto the model's grid. At the open boundary climatological seasonal temperature and salinity profiles are prescribed in cases of inflow, while radiation conditions are used for the baroclinic and barotropic velocities normal to the boundary. As already mentioned the physicochemical and biological characteristics of the Eastern Mediterranean are highly dependent on the circulation patterns and in particular to the inflowing surface waters of Atlantic origin and out-flowing of deeper Levantine Intermediate Waters which are satisfactorily described by such a kind of open boundary conditions.

The model is forced with the monthly climatological wind stress, heat and freshwater flux fields derived from the 6h ECMWF 1979-1993 re-analysis atmospheric data as described in Korres and Lascaratos (2003). These fields are mapped onto the model grid and are properly interpolated at every time step of the model's integration. The interested reader is referred to Korres and Lascaratos (2003) for a detailed description of the derivation of this climatological data set. In addition the precipitation data needed for the freshwater budget at the surface of the basin were taken from Jaeger (1976) monthly data set (horizontal resolution $5^{\circ} \times 2.5^{\circ}$.

\section{Simulations}

A significant problem often encountered in modelling studies is the absence of adequate field data for the validation of the model. In particular the Eastern Mediterranean has been sporadically studied with very fragmented data both in space and in time not only compared to the rest of the EU but even to the Western Mediterranean where high frequency monitoring 
stations were established long ago, both in coastal and offshore areas as in the case of DYnamique des Flux Atmosphériques en MEDiterranée (DYFAMED) station (http:// www.obs-vlfr.fr/sodyf).

Moreover, the significant variability in the circulation patterns of the Eastern Mediterranean (Georgopoulos et al., 2000; Theocharis et al., 1999) and the strong coupling with biological processes (Tselepides and Polychronaki, 1996) has made it evident that sparse spatial and temporal observations are prone to misrepresentation of the underlying dynamics. Until now studies of biological processes in the Eastern Mediterranean Sea have been focused on various spatial scales (large to meso-scale) in numerous campaigns - Physical Oceanography of Eastern Mediterranean (POEM), Hydrodynamics and biogeochemical fluxes in the straits of the Cretan Arc (PELAGOS), MAss Transfer and Ecosystem Response (MATER), INTERREG-N.AEGEAN, Dynamics of Matter Transfer and Biogeochemical Cycles (METROMED), Association of Physical and Biological Processes Acting on Recruitment and post Recruitment of Anchovy (ANREC), Key Coastal Processes in the Mesotrophic Skagerrak and the Oligotrophic Aegean (KEYCOP); however these studies were at best seasonal. Only two studies on the annual cycle of biological and chemical parameters have been performed: one in the Cretan Sea during the Pelagic-Benthic Coupling in the Oligotrophic Cretan Sea project (CINCS) (Tselepides and Polychronaki, 1996) and another in the Cilician Basin (Eker-Develi et al., 2006). Yet these yielded no data on phytoplankton, microzooplankton and mesozooplankton composition and biomass. There is therefore still no study of the annual cycle combining all components of the planktonic food web, organic and inorganic nutrients and hydrology, in offshore waters.

To the problem as described has to be added the significant variety of analytical methods, the limited access to raw data and a lack of in-situ sensor calibration information (of particular importance as both phosphate and nitrate in the upper euphotic zone are close to the limits of detection).

From the above it becomes evident that the validation of an ecosystem model forced climatologically in the highly variable environment of the Eastern Mediterranean is an open question. To overcome part of the difficulty a 1-D version of the model was applied to the data-rich M3A station, north of Heraklion in Crete, a suitable choice since this particular station was an ERSEM validation location during the Mediterranean Forecasting System Pilot Project (MFSPP) (Pinardi et al., 2003). Assessing the performance of a complex model depends to a large extent on the time available for tuning unconstrained parameters with a large number of degrees of freedom. The problem of such an exercise is that the model may begin to fit noise in the observational data rather than in the underlying functional relationships (Hood et al., 2006). It is thus important that the model's performance should be evaluated against a different data set than the one used for tuning. In this particular case the model was tuned with a data set acquired during the CINCS project (Tselepides and Polychronaki, 1996) and was compared with a completely different data set during MFSPP. As shown in Fig. 5 the model follows quite closely the chlorophyll concentrations as measured by the buoy sensors with the sole exception being in the first half of the year in the deeper layer $(115 \mathrm{~m})$ where simulated concentrations are significantly lower. However as the 1D setup lacks a horizontal transport mechanism, such model behaviour falls within the expected error. The other mismatch at the surface sensor during October can possibly be attributed to an extreme atmospheric event such as heavy dust deposition and to a lesser extent to a strong upwelling, enriching the surface layers with nutrients, as the signal, although obvious at both $45 \mathrm{~m}$ and $65 \mathrm{~m}$, is considerably stronger in the top-most layer.

With regard to the 3-D simulations, the model behaviour is compared against some key biological parameters measured in the North Aegean, South Aegean and N.E. Aegean west of Dardanelles during March and September 1997 in the framework of MATER project (Ignatiades et al., 2002; Lykousis et al., 2002; Siokou-Frangou et al., 2002). Thus three sub-areas in the Aegean Sea were defined following the sampling stations of MATER, namely N. Aegean (lon: 24.325.5; lat: 39.6-41.0), S. Aegean (24.0-26.5; lat: 35.4-36.0) and N.E. Aegean (25.5-26.5; lat: 39.6-40.1). Depth averaged/integrated mean monthly values were computed for the selected functional groups and are presented together with field values in Table 7. Climatologically modelled depth average chlorophyll concentrations are within the observed ranges both in north and south Aegean, while a moderate overestimation of chlorophyll concentrations in the latter area are attributed to an overestimation of vertical mixing. Basin scale models have an intrinsic inefficiency at coastal areas as coastal systems interact strongly with the open ocean at the level of ecosystem functioning, and thus require a very high resolution to simulate transport and turbulence processes in the water column. Although values for the N.E. Aegean are not available there is a general trend of lower concentrations in September compared to March, both in field data and model results. Picophytoplankton is a very important component of the food web in the Eastern Mediterranean as under such oligotrophic conditions, these cells have a competitive advantage over large phytoplankton cells such as diatoms, flagellates etc. Their small size allows them to grow and compete with the antagonistic bacteria over limiting nutrients. Thus picophytoplankton's contribution to the total biomass is very high, ranging from $57 \%$ to $82 \%$, which is satisfactorily comparable with model results: $47 \%$ to $67 \%$. Looking closely to the different areas, although simulations in terms of absolute biomass are within the observed range, they have a smaller contribution to the total phytoplankton biomass. This is not true however for S. Aegean where modelled picophytoplankton biomass is overestimated both in March and September although as indicated by the corresponding contributions there is an 
Table 7. Biological parameters measured in the North, South Aegean and west of Dardanelles during March and September (Ignatiades et al., 2002; Siokou-Frangou et al., 2002). Model values are in red.

\begin{tabular}{|c|c|c|c|c|c|c|}
\hline & \multicolumn{2}{|c|}{ N. AEGEAN } & \multicolumn{2}{|c|}{ S. AEGEAN } & \multicolumn{2}{|c|}{ N.E. AEGEAN } \\
\hline & Mar-97 & Sep-97 & Mar-97 & Sep-97 & Mar-97 & Sep-97 \\
\hline Chl- $a$ & $0.379 \pm 0.262$ & $0.260 \pm 0.126$ & $0.301 \pm 0.105$ & $0.119 \pm 0.091$ & & \\
\hline$\left(\mathrm{mgC} / \mathrm{m}^{3}\right)$ & 0.23 & 0.20 & 0.44 & 0.18 & 0.21 & 0.18 \\
\hline $\begin{array}{l}\text { Picophyto } \\
\left(\mathrm{mgC} / \mathrm{m}^{2}\right)\end{array}$ & $\begin{array}{l}1320 \pm 384 \\
(81 \%)\end{array}$ & $\begin{array}{l}817 \pm 196 \\
(76 \%)\end{array}$ & $\begin{array}{l}856 \pm 311 \\
(57 \%)\end{array}$ & $\begin{array}{l}465 \pm 64 \\
(72 \%)\end{array}$ & $\begin{array}{l}2052 \\
(80 \%)\end{array}$ & $\begin{array}{l}1326 \pm 539 \\
(82 \%)\end{array}$ \\
\hline & $1187(50 \%)$ & $1060(48 \%)$ & $2023(67 \%)$ & $1107(47 \%)$ & $1124(46 \%)$ & $1134(48 \%)$ \\
\hline $\begin{array}{l}\text { Bacteria } \\
\left(\mathrm{mgC} / \mathrm{m}^{2}\right)\end{array}$ & $1406 \pm 327$ & $\begin{array}{l}1470 \pm 273 \\
(69 \%)\end{array}$ & $\begin{array}{l}1423 \pm 43 \\
(75 \%)\end{array}$ & $\begin{array}{l}1505 \pm 432 \\
(59 \%)\end{array}$ & $1403 \pm 142$ & $\begin{array}{l}1251 \pm 107 \\
66 \%)\end{array}$ \\
\hline & $1075(44 \%)$ & $1376(46 \%)$ & $1572(47 \%)$ & $1571(45 \%)$ & $907(43 \%)$ & $1145(42 \%)$ \\
\hline $\begin{array}{l}\text { Heter. Nanoflagellates } \\
\left(\mathrm{mgC} / \mathrm{m}^{2}\right)\end{array}$ & & $\begin{array}{l}418 \pm 90 \\
(20 \%)\end{array}$ & $\begin{array}{l}192 \pm 54 \\
(10 \%)\end{array}$ & $\begin{array}{l}812 \pm 376 \\
(32 \%)\end{array}$ & & $\begin{array}{l}301 \pm 31 \\
(16 \%)\end{array}$ \\
\hline & $576(24 \%)$ & $652(22 \%)$ & $875(26 \%)$ & $725(21 \%)$ & $489(23 \%)$ & $579(21 \%)$ \\
\hline Primary Prod. & $1406 \pm 362$ & $253 \pm 70$ & $574 \pm 176$ & $218+63$ & $2339 \pm 905$ & $221 \pm 13$ \\
\hline$\left(\mathrm{mgC} / \mathrm{m}^{2} \mathrm{~d}\right)$ & 1445 & 1854 & 2123 & 2385 & 1169 & 1955 \\
\hline Bacteria Prod. & $48 \pm 31$ & $60 \pm 11$ & $75 \pm 9$ & $58 \pm 13$ & $110 \pm 77$ & 71 \\
\hline$\left(\mathrm{mgC} / \mathrm{m}^{2} \mathrm{~d}\right)$ & 179 & 346 & 431 & 380 & 161 & 318 \\
\hline Total Autotrophs & $1621( \pm 426)$ & $1072( \pm 227)$ & $1488( \pm 364)$ & $645( \pm 81)$ & $2568( \pm 78)$ & $1627( \pm 616)$ \\
\hline$\left(\mathrm{mgC} / \mathrm{m}^{2}\right)$ & 2235 & 2203 & 3000 & 2337 & 2429 & 2384 \\
\hline Total Heterotrophs & $1847( \pm 364)$ & $2127( \pm 225)$ & $1866( \pm 94)$ & $2538( \pm 607)$ & $2421( \pm 564)$ & $1098( \pm 195)$ \\
\hline$\left(\mathrm{mgC} / \mathrm{m}^{2}\right)$ & 2408 & 2973 & 3367 & 3455 & 2104 & 2723 \\
\hline
\end{tabular}

overestimation in all phytoplankton groups only in September. Heterotrophic microbes are very important since a large proportion, up to or exceeding $50 \%$ of the total flux of matter and energy in marine food webs passes through such organisms by means of dissolved organic matter (Fuhrman, 1999). In oligotrophic waters the bacterial biomass, depth integrated over the euphotic zone often exceeds that of phytoplankton, although heterotrophic bacterial production is low, with population doubling-times at a weekly rate. Even with this slow growth, bacteria consume significant amounts of organic carbon, which constitute a large fraction of primary production (Azam et al., 1983). Thus it is suggested that a relatively small phytoplankton biomass must turn over much faster than the bacteria in order to feed the larger bacterial biomass (Fuhrman, 1999). Depth integrated bacterial biomass as produced by the model is very close to field values although in terms of its contribution to the total heterotrophic biomass, model values are lower, indicating an overestimation of other heterotrophs. Another significant functional group, in this particular environment, are the heterotrophic nanoflagellates. These together with the bacteria play a significant role in the development of a microbial loop, which is a rather dominant process for large parts of the area. The model success against the limited field data is both positive and negative with an overestimation during March in the S. Aegean and September in the N.E. Aegean. A prominent characteristic of the model results in March and September is that the corresponding contribution of bacteria and heterotrophic nanoflagellates to the total heterotrophic biomass is rather constant exhibiting smaller variability between areas and months than the one observed in-situ. In terms of total phytoplanktonic and heterotrophic biomasses simulations are either in the upper limit of the observations or are exceeding them, with only exception during March in the N.E. Aegean. Further analysis with a 1-D model version, has shown that there is a tendency for a more productive system in the shallow areas close to the coast due to a strong coupling with benthos, while in offshore waters, model results are very close to observations. However looking in the monthly evolution of stocks there is an obvious strengthening of the microbial loop during stratification period, with the more productive coastal areas exhibiting an almost seasonal shift between microbial and classical pathways. This is particularly obvious in the N. Aegean due to three characteristics: the relatively shallow waters enabling a strong benthic-pelagic coupling, the riverine inputs and the Black Sea waters with the latter affecting the wider area of N. Aegean.

Increased primary production rates have been measured during March 1997 in the whole N. Aegean, with values decreasing approximately by one order of magnitude in September. Values are also low in S. Aegean with March exhibiting higher rates. Model rates are generally overestimated with only exception during March in the N. Aegean when are very similar to in-situ while in the N.E. Aegean are close to the lower limit. Overestimations are also produced by the model for the bacterial production rate with higher 

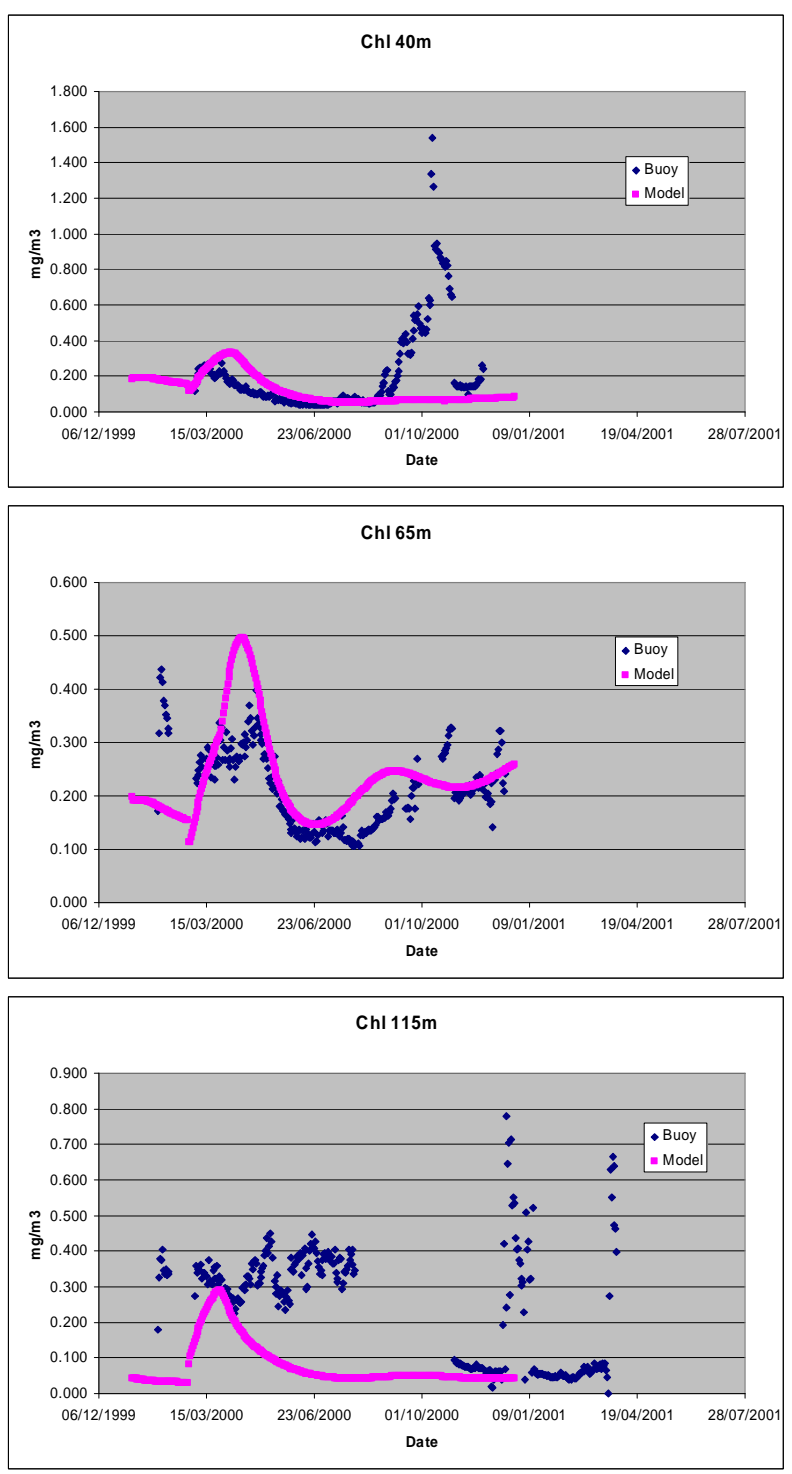

Fig. 5. Comparison of 1-D model Chl- $a$ concentration at various depths against M3A buoy data.

values in the south. Field observations exhibit a small variability between north and south with the exception of the area close to Dardanelles where bacteria are more active. This is attributed to the characteristics of the influx waters from Dardanelles and in particular to the enrichment with DOC stimulating heterotrophic bacteria. Using the 1-D model again it was verified that most of the primary production is directed to the carbohydrate production (mean $86 \%$ ) with net carbon assimilation being only $14 \%$. Therefore it seems that the simulated "dissolved" production is significantly overestimated as compared to existing data through an overestimated photosynthesis rate. Furthermore the overestimation in the production of dissolved organic matter is most probably responsible for the overestimation in bacterial production.
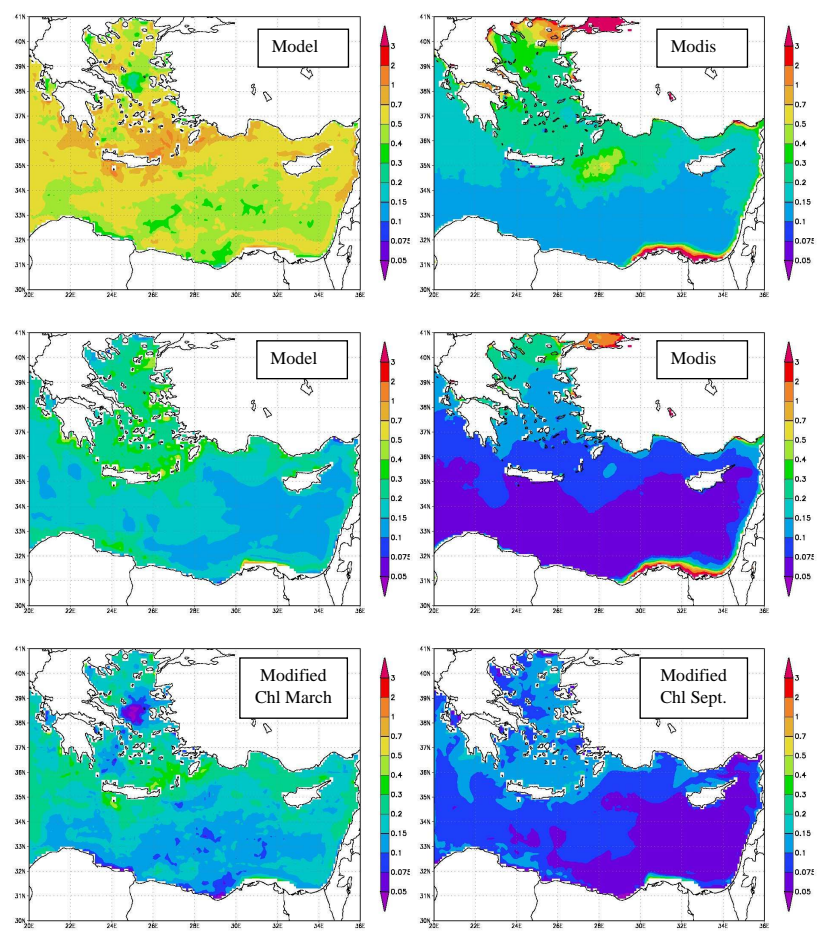

Fig. 6. March (top), September (middle) monthly mean surface Chl $\left(\mathrm{mg} / \mathrm{m}^{3}\right)$. Climatological model result (left) - MODIS (right) data over 2002-2007 period. Model results with modified chl formulation (bottom) for March (left) and September (right).

Although advances in satellite remote sensing techniques during the last twenty years have made possible a considerable progress in our knowledge of spatial and temporal variations in algal biomass in various regions of the world ocean (Bricaud et al., 2002), the oligotrophic character of the Eastern Mediterranean (case I waters) requires regionally tuned empirical algorithms. Comparisons of different ocean colour sensors (Bricaud et al., 2002) and different algorithms (Sancak et al., 2005) have shown that there are large over-estimations at low chlorophyll levels $<0.15 \mathrm{mg} / \mathrm{m}^{3}$ and although alternative algorithms have been proposed none of these has been widely accepted so far. Considering these limitations a model validation is attempted with simulated surface mean monthly chlorophyll concentrations compared against available satellite images. Figure 6 show the simulated monthly mean surface chlorophyll concentrations during March and September against monthly mean MODIS chlorophyll over 2002-2007 period. Model results seem to systematically overestimate chlorophyll compared to MODIS both in March and September. This is also true for the remaining months (not shown) as well as for the three areas examined further above in which the performance of the model in terms of depth averaged chlorophyll concentration was rather satisfactory. Model performance was also very good in the M3A station, indicating that either there is 


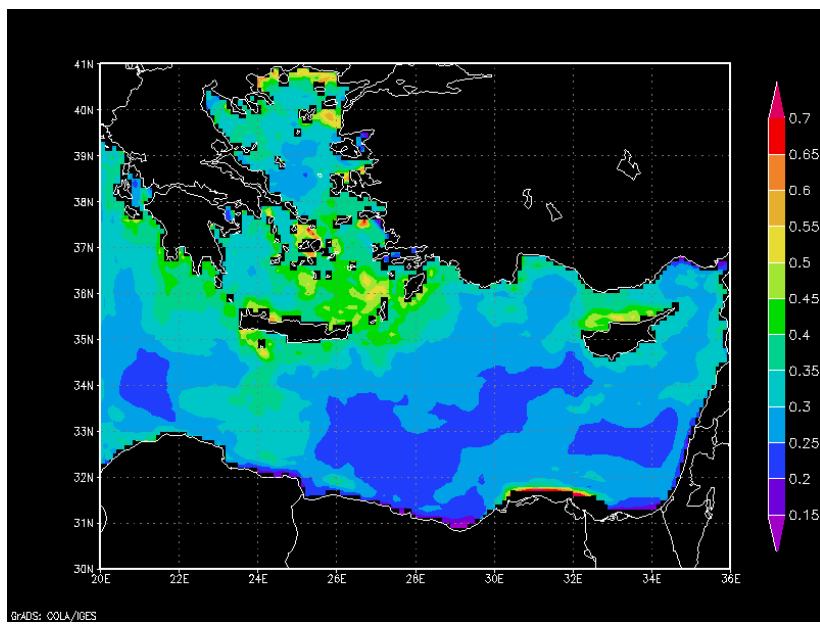

Fig. 7. Mean annual, depth average chlorophyll concentration $\left(\mathrm{mg} / \mathrm{m}^{3}\right)$.

a problem with the model chlorophyll calculation, particularly at the surface layers or as mentioned above the existing algorithms for the satellite images might be inappropriate. Attempting to analyse this issue, an additional simulation was performed with a modified chlorophyll synthesis formulation adopting a varying chl/C(z) ratio (Eq. 37) that is calculated following Geider et al. (1997) formulation for balanced growth conditions. In this way light acclimation is taken into account using the steady state function for chl/C which is expected to hold under balanced growth/slowly varying light conditions (climatological forcing). Model results (Fig. 6) exhibit a better agreement with MODIS data and as the balanced growth function stems (as the steady state) from the same Geider formulation employed in the dynamic chlorophyll synthesis model, we can only guess that the overestimation in the standard model run is linked to an overestimation in the model's simulated productivity rate. Notice that simulated biomasses in the two runs are similar at near the surface, with major differences being only in the Chlorophyll content.

$\operatorname{chl} / C(z)=p_{-} q \operatorname{chl} c /\left(1+p_{\_} a l p h a_{-} \operatorname{chl} \times \operatorname{Irr}(z) \times p_{-} q \operatorname{chlc}\right) /$ $\left(2 \times\right.$ Photo_max $_{-}$

Finally mean annual model results are also compared against general trends and qualitative characteristics of the system as described in the literature. Looking at the depth average chlorophyll concentrations (Fig. 7) there is a characteristic coupling between the biology and the physics as shown by the spatial chlorophyll distribution. This phenomenon of patchiness is also observed in the field and is caused by mesoscale turbulence on scales of 1-100 km where ageostrophic motions cause strong local up- and downwelling, to which the plankton ecosystem responds dramatically, giving modulation in plankton abundance and commensurate changes in primary and secondary production and

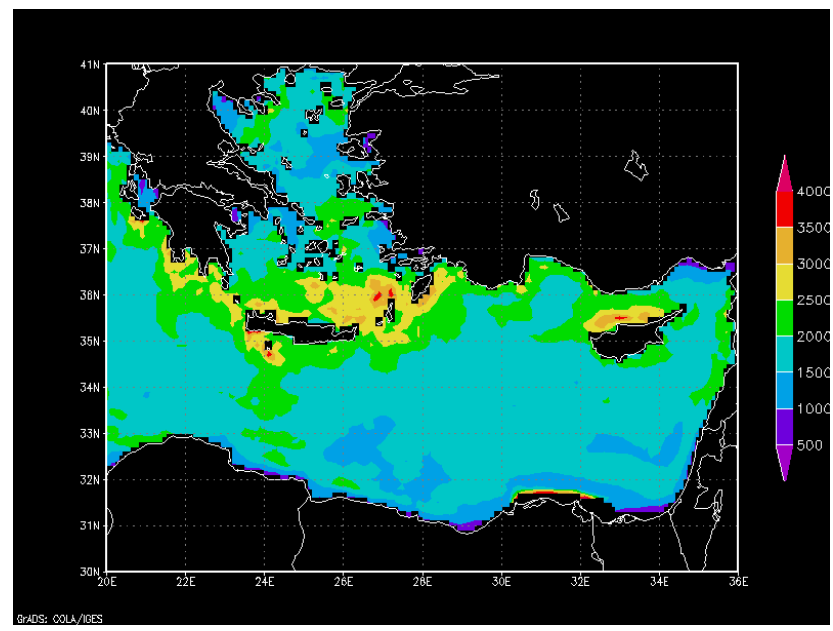

Fig. 8. Mean annual, depth integrated primary productivity $\left(\mathrm{mgC} / \mathrm{m}^{2} \mathrm{~d}\right)$.

in community structure. It is worth mentioning that the existence of patchiness poses problems when one tries to obtain a statistically significant estimate of primary production from a limited number of samples collected by ship, or by remote sensing (ocean colour) and it also poses problems in designing large-scale models of the ecosystem, with gridspacing too large to resolve mesoscale turbulence. Generally the known more productive areas of N. Aegean, Dardanelles and Nile are effectively reproduced by the model. Mean annual depth integrated primary productivity rate (Fig. 8) is overestimated by the model and in particular the wider area of south Aegean along the sills of the Cretan arc. This model behaviour is due to the uplift of deep and rich in nutrients waters, resulting in the enrichment of the euphotic zone with a subsequent overestimation in both rates and stocks. This is not only evident for phytoplankton, with bacteria (Fig. 9) and heterotrophs (Fig. 10) exhibiting a similar picture, illustrating the control of physical processes (mixing) over the biology. Further analysis in terms of the hydrodynamic model behaviour is considered necessary and will be the subject of future work. The mean annual depth integrated bacterial production (Fig. 9) exhibits the expected north - south trend in the Aegean Sea although as already mentioned simulated values are overestimated. Following chlorophyll the spatial variability of bacterial productivity illustrates the coupling between bacteria and hydrodynamics, as because of their small size, bacteria can react very fast to the short changes of the extremely variable environment of the East Mediterranean. Their small size with a large surface to volume ratio enables the uptake of dissolved nutrients more efficiently compared to bigger organisms. Although the model fails to show increased rates around the Dardanelles, as detailed measurements in this area are missing (currently there is an effort towards this through the Southern European Seas: Assessing and Modelling Ecosystem changes project - 


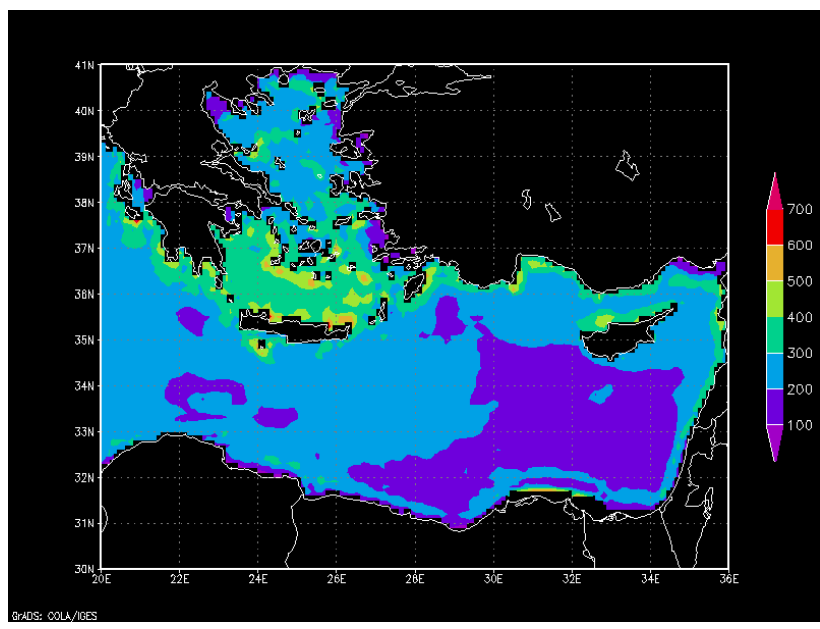

Fig. 9. Mean annual, depth integrated bacterial productivity $\left(\mathrm{mgC} / \mathrm{m}^{2} \mathrm{~d}\right)$.

SESAME), it precludes us from an in depth analysis.

As mentioned above, one of the most prominent hydrological patterns of the Eastern Mediterranean is the existence of mesoscale eddies significantly affecting the biology of the area in question. Such an eddy system is the Rhodes coldcore eddy, the centre of which is the site of the greatest phytoplankton productivity to be found anywhere in the open Eastern Mediterranean, mainly by diatoms and other large cells while the Bacteria/Phyto ratio is significantly lower compared to the rest of the Levantine basin (Krom et al., 2003). Some of the characteristics of this eddy are: deep mixing down to $3000 \mathrm{~m}$, the development of a Deep Chlorophyll Maximum (DCM) at approximately $60 \mathrm{~m}$ and the quite high nutrient concentrations during mixing. The model seems to reproduce this system as shown in the cross-sections of Fig. 11, with waters being uplifted at the area of the eddy $\left(28^{\circ} \mathrm{E}-30^{\circ} \mathrm{E}\right)$ during March and with a significant DCM being developed during September, although the core of this feature lies deeper at approximately $90 \mathrm{~m}$. In the north south cross-sections in the same figure the model is more productive with respect to chlorophyll in the north parts during March but not in September when significant phytoplanktonic activity takes place in the southern deeper parts of the basin following the nutricline.

\section{Conclusions}

In the preliminary application of BFM in the Eastern Mediterranean even though the model behaviour cannot be claimed as perfect, the results show real promise for the future. Due to the shortage of available in-situ data the model was validated mainly in three sub areas in the Aegean Sea exhibiting a good agreement with observations, responding efficiently to the variability in mixing, nutrient supply and

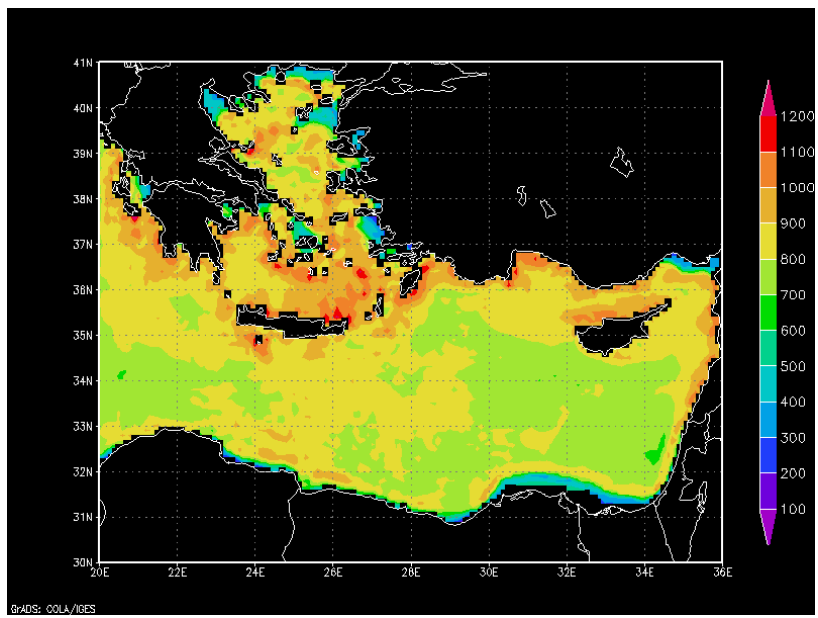

Fig. 10. Mean annual, depth integrated heterotrophic flagellate biomass $\left(\mathrm{mgC} / \mathrm{m}^{2}\right)$.
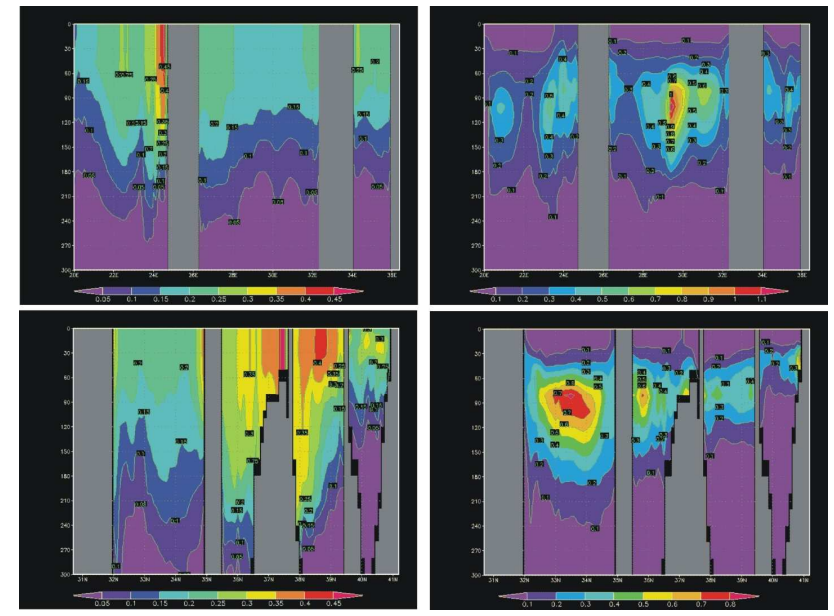

Fig. 11. Vertical cross sections of Chl-a concentrations $\left(\mathrm{mg} / \mathrm{m}^{3}\right)$ across latitude $35^{\circ} \mathrm{N}$ (top row), and longitude $25^{\circ} \mathrm{E}$ (bottom row) in March (left column) and September (right column).

light conditions. Overestimations produced along the Cre$\tan$ arc are attributed to inefficiencies of the physical model and will be further looked at in the future. Overall the model was able to reproduce the full range of scales of variability and of marine ecosystem behaviour from the eutrophic in gulfs and shallow coastal waters to extremely oligotrophic in outer areas. Bearing in mind that open ocean processes dominate the Eastern Mediterranean ecosystem, and that the limited extent of the continental shelf means that the general circulation has a significant influence on coastal processes, the model has produced some key characteristics such as: i) primary production is mainly controlled by mixing processes ii) stratification period is characterised by the development of a deep chlorophyll maximum and a dominant microbial loop iii) in coastal areas the herbivorous food web is 
more important although the dominant carbon flux along the trophic web can seasonally shift from the herbivorous to the microbial pathway and iv) inputs from rivers and the Dardanelles are exported from the coastal to the offshore areas.

Important issues such as the role of viruses and the influence of water inputs particularly in the north Aegean, will all be high priority future tasks. Models should provoke questions as well as provide quantitative and qualitative insights (Blackford et al., 2004), and in this respect the Eastern Mediterranean coupled physical - biological model already adequately fulfils its purpose.

The model presented here is a significant advance in the coupled hydrodynamic-ecosystem modelling of the Eastern Mediterranean and will form the basis of several modelling studies. It will provide the scientific and technological knowledge to underpin the construction of an operational forecast model for the marine ecosystem and an expert system which can link the model with our knowledge and experience of the environment.

Finally the implementation of the data assimilation system for the marine ecosystem of the Eastern Mediterranean will enable us to assess the potential of the modelling system to predict short and long-term changes in the marine ecosystem structure. To achieve predictive capabilities, deterministic ecosystem models need to be updated with biological, physical and chemical data at relevant space-time scales. The imperative need for the development of marine operational systems has led to a significant increase in the effort being invested in such techniques (Allen et al., 2003; Hoang et al., 1997; Hoteit et al., 2002; Hoteit et al., 2004; Hoteit et al., 2003; Natvik and Evensen, 2003; Triantafyllou et al., 2003a; Triantafyllou et al., 2003b; Triantafyllou et al., 2001). Advanced assimilation filters developed during MFSTEP have been incorporated in the ecosystem model described in this work and are presented in a companion paper to this volume.

Acknowledgements. This work was supported by the Mediterranean Forecasting System - Towards Environmental Predictions Project (MFSTEP). Contract no. EVK3-CT-2002-00075.

Edited by: N. Pinardi

\section{References}

Abdel-Hamid, M. I., Shaaban-Dessouki, S. A. and Skulberg, O. M.: Water quality of the River Nile in Egypt. 1. Physical and chemical characteristics, Archiv. Hydrobiol., 90, 283-310, 1992.

Aksnes, D. L. and Egge, J. K.: A theoretical model for nutrient uptake in phytoplankton, Marine Ecology Progress Series, 70, 65-72, 1991.

Allen, J. I., Ekenes, M., and Evensen, G.: An Ensemble Kalman Filter with a complex marine ecosystem model: Hindcasting phytoplankton in the Cretan Sea, Ann. Geophys., 21, 399-411, 2003, http://www.ann-geophys.net/21/399/2003/.
Allen, J. I., Siddorn, R. J., Blackford, C. J., and Gilbert, J. F.: Turbulence as a control on the microbial loop in a temperate seasonally stratified marine systems model, J. Sea Res., 52, 1-20, 2004.

Azam, F., Fenchel, T., Field, J. G., Gray, J. S., Meyer-Reil, L. A., and Thingstad, F.: The ecological role of water - column microbes in the sea, Mar. Ecol. Progress Ser., 10, 257-263, 1983.

Azov, Y.: Eastern Mediterranean - a marine desert? EMECS', 90(23), 225-232, 1991.

Baretta-Bekker, J. G., Baretta, J. W., and Ebenhoh, W.: Microbial dynamics in the marine ecosystem model ERSEM II with decoupled carbon assimilation and nutrient uptake, J. Sea Res., 38, 195-211, 1997.

Baretta-Bekker, J. G., Baretta, J. W., and Rasmussen, E.: The microbial foodweb in the European regional Seas Ecosystem Model, Netherlands J. Sea Res., 33, 363-379, 1995.

Baretta, J. W., Ebenhoh, W., and Ruardij, P.: The European Regional Seas Ecosystem Model, a complex marine ecosystem model, Netherlands J. Sea Res., 33, 233-246, 1995.

Blackford, C. J., Allen, J. I., and Gilbert, J. F.: Ecosystem dynamics at six contrasting sites: a generic modelling study, J. Mar. Syst., 52, 199-215, 2004.

Blumberg, A. F. and Mellor, G. L.: A Coastal Ocean Numerical Model in: Sunderman, J. and Holtz, K., Mathematical Modelling of Estuarine Physics. Proceedings of the International Symposium, Springer-Verlag Berlin, Hamburg, 203-214, 1978.

Blumberg, A. F. and Mellor, G. L.: A description of a threedimensional coastal ocean circulation model, in: Heaps, N. S., Three-Dimensional Coastal Ocean Circulation Models, Coastal Estuarine Science, AGU, Washington, D.C., 1-16, 1987.

Bratbak, G., Heldal, M., Thingsta, T. F., Riemann, B., and Haslnund, O. H.: Incorporation of viruses into the budget of microbial C-transfer. A first approach, Mar. Ecol. Progress Ser., 83, 273-280, 1992.

Bricaud, A., Bosc, E., and Antoine, D.: Algal biomass and sea surface temperature in the Mediterranean Basin. Intercomparison of data from various satellite sensors, and implications for primary production estimates, Remote Sens. Environ., 81, 163-178, 2002.

Bryden, H. L., Candela, J., and Kinder, T. H.: Exchange through the Strait of Gibraltar, Prog. Oceanog., 33, 201-248, 1994.

Crise, A., Allen, J. ., Baretta, J., Crispi, G., Mosetti, R., and Solidoro, C.: The Mediterranean pelagic ecosystem response to physical forcing, Progress Oceanogr., 44, 219-243, 1999.

Droop, M. R.: The nutrient status of algal cells in continuous culture, J. Mar. Biol. Assoc., 54, 825-855, 1974.

Eker-Develi, E., Erkan Kideys, A., and Tugrul, S.: Role of Saharan dust on phytoplankton dynamics in the northeastern Mediterranean, Mar. Ecol. Prog. Ser., 374, 61-75, 2006.

Fuhrman, J. A.: Marine viruses and their biogeochemical and ecological effects, Nature, 399, 541-548, 1999.

Geider, R. J., Mac Intyre, H. L., and Kana, T. M.: A dynamic regulatory model of phytoplanktonic acclimation to light, nutrients and temperature, Limnol. Oceanogr., 43, 679-694, 1998.

Georgopoulos, D., Chronis, G., Zervakis, V., Lykousis, V., Poulos, S., and Iona, A.: Hydrology and circulation in the Southern Cretan Sea during the CINCS experiment (May 1994-September 1995), Progress Oceanogr., 46, 89-112, 2000.

Gill, A. E.: Atmosphere-Ocean Dynamics, Academic Press, New York, 662 pp, 1982. 
Heldal, M. and Bratbak, G.: Production and decay of viruses in aquatic environments, Mar. Ecol. Progress Ser., 72, 205-212, 1991.

Hoang, H. S., De Mey, P., Tallagrand, O., and Baraille, R.: Adaptive filtering: Application to satellite data assimilation in oceanography, J. Dynam. Atmos. Ocean., 27, 257-281, 1997.

Hood, R. R., Laws, A. E., Armstrong, A. R., Bates, R. N., Brown, W. C., Carlson, A. C., Chai, F., Doney, C. S., Falkowski, G. P., Feely, A. R., Friedrichs, A. M. M., Landry, R. M., Moore, J. K., Nelson, M. D., Richardson, L. T., Salihoglu, B., Schartau, M., Toole, A. D., and Wiggert, D. J.: Pelagic functional group modeling: Progress, challenges and prospects, Deep Sea Res. II, 53, 459-512, 2006.

Hoteit, I., Pham, D. T., and Blum, J.: A semi-evolutive partially local filter for data assimilation, Mar. Pollut. Bull., 43(7-12), 164174, 2002.

Hoteit, I., Triantafyllou, G., and Petihakis, G.: Towards a data assimilation system for the Cretan sea ecosystem using a simplified Kalman filter, J. Mar. Syst., 45, 159-171, 2004.

Hoteit, I., Triantafyllou, G., Petihakis, G., and Allen, J. I.: A singular evolutive Kalman filter to assimilate real in-situ data in a 1-D marine ecosystem model, Ann. Geophys., 21, 389-397, 2003, http://www.ann-geophys.net/21/389/2003/.

Ignatiades, L., Psarra, S., Zervakis, V., Pagou, K., Souvermezoglou, E., Assimakopoulou, G., and Gotsi-Skreta, O.: Phytoplankton size-based dynamics in the Aegean Sea (Eastern Mediterranean), J. Mar. Syst., 36, 11-28, 2002.

Jaeger, L.: Monatskarten des Niederschlags fur die ganze Erde, Ber. Dtsch. Wetterdienste, 18(1839), 1-38, 1976.

Korres, G. and Lascaratos, A.: A one-way nested eddy resolving model of the Aegean and Levantine basins: Implementation and climatological runs, Analles Geophysicae, 21, 205-220, 2003.

Krom, M., Groom, S., and Zohary, T.: The Eastern Mediterranean. In: K.D. Black and G.B. Shimmield (Editors), Biogeochem. Mar. Syst., Blackwell Publishing, Oxford, 91-126, 2003.

Lykousis, V., Chronis, G., Tselepides, A., Price, N. B., Theocharis, A., Siokou-Frangou, I., Van Wambeke, F., Donavaro, R., Stavrakakis, S., Duineveld, G., Georgopoulos, D., Ignatiades, L., Souvermezoglou, E., and Voutsinou-Taliadourou, F.: Major outputs of the recent multidisciplinary biogeochemical researches undertaken in the Aegean Sea, J. Mar. Syst., 33-34, 313-334, 2002.

McGill, D.: The relative supplies of phosphate, nitrate and silicate in the Mediterranean Sea, Rapports et Proces-Verbaux des Reunions Commission Internationale pour l'Exploration Scientifique de la Mer Mediterranee, 18, 734-744, 1965.

Mellor, G. L.: User's guide for a three-dimensional primitive equation, numerical ocean model (July 1998 version), Princeton University, 1998.

Mihailov, A. A.: On the phytoplankton of the Aegean Sea, Trudy Sevastopol, Biol. St., 17, 3-12, 1964.

Moutin, T. and Raimbault, P.: Primary production, carbon export and nutrients availability in western and eastern Mediterranean Sea in early summer 1996 (MINOS cruise), J. Mar. Syst., 33-34, 273-288, 2002.

Natvik, L. and Evensen, G.: Assimilation of ocean colour data into a biochemical model of the north Atlantic. Part-I. data assimilation experiments, J. Mar. Syst., 40-41, 127-153, 2003.

Parsons, T., Takahashi, M., and Hargrave, B.: Biological oceano- graphic processes, Pergamon Press, 330 pp., 1973.

Pinardi, N. and Masetti, E.: Variability of the large scale general circulation of the Mediterranean Sea from observations and modelling: a review, Palaeogeography, Palaeoclimatology, Palaeoecology, 158, 153-174, 2000.

Pinardi, N., Allen, I., Demirov, E., De Mey, P., Korres, G., Lascaratos, A., Le Traon, P.-Y., Maillard, C., Manzella, G., and Tziavos, C.: The Mediterranean ocean forecasting system: first phase of implementation (1998-2001), Ann. Geophys., 21, 3-20, 2003, http://www.ann-geophys.net/21/3/2003/.

Polat, C. and Tugrul, S.: Chemical exchange between the Mediterranean and Black Sea via the Turkish straits, CIESM Science Series, Bull. De l'Institut Oceanog, 2(17), 167-186, 1996.

Proctor, L. M. and Fuhrman, J. A.: Viral mortality of marine bacteria and cyanobacteria, Nature, 343, 60-62, 1990.

Sancak, S., Besiktepe, T. S., Yilmaz, A., Lee, M., and Frouin, R.: Evaluation of SeaWifs chlorophyll-a in the Black and Mediterranean Seas, Int. J. Remote Sens., 26(10), 2045-2060, 2005.

Siokou-Frangou, I., Bianchi, M., Christaki, U., Christou, E.D., Giannakourou, A., Gotsis, O., Ignatiades, L., Pagou, K., Pitta, P., Psarra, S., Souvermezoglou, E., Van Wambeke, F., and Zervakis, V.: Carbon flow in the planktonic food web along a gradient of oligotrophy in the Aegean Sea (Mediterranean Sea), J. Mar. Syst., 33-34, 335-353, 2002.

Skoulikidis, N. T.: Significance evaluation of factors controlling river water composition, Env. Geol., 22, 178-185, 1993.

Suttle, C. A., Chan, A. M., and Cottrell, M. T.: Infection of phytoplankton by viruses and reduction of primary production, Nature, 347, 467-469, 1990.

Theocharis, A., Balopoulos, E., Kioroglou, S., Kontoyiannis, H., and Iona, A.: A synthesis of the circulation and hydrography of the South Aegean Sea and the Straits of the Cretan Arc (March 1994-January 1995), Progress Oceanogr., 44, 469-509, 1999.

Theocharis, A., Georgopoulos, D., Lascaratos, A., and Nittis, K.: Water masses and circulation in the central region of the Eastern Mediterranean: Eastern Ionian, South Aegean and Northwest Levantine, Deep-Sea Res. II, 40(6), 1121-1142, 1993.

Triantafyllou, G., Hoteit, I., and Petihakis, G.: A singular evolutive interpolated Kalman filter for efficient data assimilation in a 3D complex physical-biogeochemical model of the Cretan Sea, J. Marine Syst., 40-41, 213-231, 2003a.

Triantafyllou, G., Hoteit, I., and Petihakis, G.: The use of global and local EOFs for the assimilation of biochemical data into Cretan Sea ecosystem model, EGS 2003, Geophys. Res. Abstracts, 5, 10497, 2003b.

Triantafyllou, G., Hoteit, I., Petihakis, G., Allen, J. I., Pollani, A. and Dounas, C.: Efficient Reduced Kalman Filtering for Assimilating the Spatial and Temporal Variability of the Cretan Ecosystem, 33rd international Liege Colloquium on Ocean Dynamics, The use of Data Assimilation in Coupled Hydrodynamic, Ecological and Bio-Geo-Chemical Models of the Ocean, Liege, 2001.

Tselepides, A. and Polychronaki, T.: Pelagic-benthic coupling in the oligotrophic Cretan Sea (Ne Mediterranean), Final Report, IMBC, Iraklio, 1996.

Tugrul, S., Besiktepe, S. T., and Salihoglou, I.: Nutrient exchange fluxes between the Aegean and Black Seas through the Marmara Sea, Mediterranean Marine Science, 3(1), 33-42, 2002. 
Vichi, M., Baretta, J., Baretta-Bekker, J., Ebenhoh, W., Kohlmeier, C., Ruardij, P., Pinardi, N., and Zavatarelli, M.: European Regional Seas Ecosystem Model III, Review of the biogeochemical equations, www.bo.ingv.it/ersem3/ERSEM_III_report.lyx, v1. 6 2004/07/28 10:44:29 mav Exp, 2004.
Vichi, M., Pinardi, N., and Masina, S.: A generalized model of pelagic biogeochemistry for the global ocean ecosystem. Part I: Theory, J. Mar. Syst., 64, 89-109, 2007. 